\title{
Growth Factor Interactions in Bone Regeneration
}

\author{
Diederik H.R. Kempen, M.D., ${ }^{1}$ Laura B. Creemers, Ph.D., Jacqueline Alblas, Ph.D., ${ }^{1}$ Lichun Lu, Ph.D., ${ }^{2}$ \\ Abraham J. Verbout, M.D., Ph.D., Michael J. Yaszemski, M.D., Ph.D., \\ and Wouter J.A. Dhert, M.D., Ph.D.,3
}

Bone regeneration is a complex process regulated by a large number of bioactive molecules. Many growth factors and cytokines involved in the natural process of bone healing have been identified and tested as potential therapeutic candidates to enhance the regeneration process. Although many of these studies show an enhancement of the bone regeneration process by a single drug therapy, in vivo bone regeneration is the result of a complex interplay between the applied growth factor and various endogenous produced growth factors. To investigate these growth factor interactions, various studies have investigated the effect of growth factor combinations on bone regeneration. This review provides an overview of the growth factor and cytokine combinations tested in translational bone regeneration studies and shows that their interaction may result in an enhancement or inhibition of bone formation.

\section{Introduction}

B ONE IS, AFTER BLOOD, the most commonly transplanted tissue. Worldwide, an estimated 2.2 million grafting procedures are performed annually to repair bone defects in orthopedics, neurosurgery, and dentistry. ${ }^{1}$ Given the demographic challenges of a growing and aging population, this number is expected to increase. The increasing number of grafting procedures and the disadvantages of current autograft treatments (e.g., limited graft quantity and donor-site morbidity) and allograft treatments (e.g., reduced rate of graft incorporation and risk of disease transmission) drive the quest for alternative methods to treat large bone defects. ${ }^{2-6}$

The ability of devitalized, demineralized bone to induce ectopic bone formation and the recognition that proteins were responsible for this bone induction launched the promising strategy of bone tissue engineering based on bioactive molecules. ${ }^{7,8}$ Since then, various proteins with an important role in this autoinductive process were isolated and investigated for their therapeutic potential in bone regeneration, including bone morphogenetic proteins (BMPs), transforming growth factor-beta (TGF- $\beta$ ), fibroblast growth factor (FGF), insulin-like growth factor (IGF), vascular endothelial growth factor (VEGF), platelet-derived growth factor (PDGF), epidermal growth factor, parathyroid hormone (related protein) (PTH/PTHrP), and interleukins (IL). Although many studies show an enhancement of the regeneration process by applying one of these proteins, the exact molecular coordination of the bone regeneration process has not been fully defined. Moreover, as various growth factors and cytokines are involved simultaneously in natural bone healing, the combined addition of several factors in specific temporal fashion is likely to be more effective in exogenous stimulation of healing.

Normal bone regeneration (e.g., during fracture healing) is a complex process that involves a large number of growth factors and cytokines for its regulation. No matter how influential one factor may appear in the process, its action in isolation may have little effect without interaction with endogenously produced growth factors and cytokines. Therefore, determination of growth factor interactions is essential to understand and/or control the process of bone regeneration. This review provides an overview of the combinations of growth factors that have been investigated in translational bone regeneration studies. Since most research focuses on combinations with BMPs due to their potent osteoinductive capacity, these growth factors will play a central role in this review.

\section{BMPs and Their Combinations}

Over 20 members of the BMP family have been identified and at least 7 of them have documented osteoinductive capacities. ${ }^{9}$ The biologically active form of BMPs consist of 30-38 kDa proteins composed of two disulfide-linked polypeptide subunits. On the basis of their amino acid sequence homology, the osteoinductive BMPs have been divided into

\footnotetext{
${ }^{1}$ Department of Orthopedics, University Medical Center, Utrecht, The Netherlands.

${ }^{2}$ Tissue Engineering and Biomaterials Laboratory, Departments of Orthopedic Surgery and Biomedical Engineering, Mayo Clinic College of Medicine, Rochester, Minnesota.

${ }^{3}$ Faculty of Veterinary Medicine, Utrecht University, Utrecht, The Netherlands.
} 
separate subgroups, which include the BMP-2/-4 group and the osteogenic protein-1 or OP-1 group (BMP-5 to -8). ${ }^{10-12}$ Most research in the field of bone regeneration focuses on the commercially available BMP homodimers. However, BMP members can also form heterodimers consisting of, for example, one BMP-2 and one BMP-7 subunit and displaying much higher affinities for BMP receptors than homodimers. ${ }^{13}$ Given the number of BMP genes, the possible number of combinations is large. So far, native BMP-heterodimers have not been identified in vivo and their separation from homodimers in experimental studies remains difficult because of the biochemical similarity between BMPs. ${ }^{11,14}$

Although BMPs are involved in numerous developmental and pathophysiological processes, their effects on bone formation have been studied most extensively. In bone, they are synthesized by skeletal cells such as osteoblasts and sequestered in the extracellular bone matrix. ${ }^{7,15,16}$ In vitro, BMPs can differentiate mesenchymal stem cells into the osteoblastic phenotype. ${ }^{17,18}$ When implanted ectopically, the osteoinductive BMPs can initiate the complete cascade of bone formation, including the migration of mesenchymal stem cells and their differentiation into osteoblasts. ${ }^{11}$ This bone induction occurs through endochondral as well as intramembranous ossification and results in the formation of normal woven and/or lamellar bone. ${ }^{11,19}$

In contrast to the numerous studies in which the effect of separate BMP homodimers was investigated, few studies focused on the combined administration of BMP family members (Table 1). ${ }^{20-25}$ So far, none of the studies using BMP homodimers has been able to show an enhanced effect of the combinations. $^{23-25}$ Neither the in vitro capacity to induce osteogenic cell differentiation nor the in vivo capacity to induce ectopic bone showed an effect of administration of homodimer mixtures compared to an equal dose of one of the BMP homodimers separately. In contrast to the homodimer mixtures, several recombinant BMP heterodimers (particularly BMP-2/-6, BMP-2/-7, and BMP-4/-7) were more potent in vitro and in vivo compared to a corresponding amount of their homodimers. ${ }^{24,25}$ This increase in osteoinductive activity was even 20-fold in case of BMP-2/-7. Also, transduction studies using nonviral or adenoviral osteoinductive BMP vectors showed more efficient induction of osteoblast differentiation and spinal fusion. ${ }^{18,21,26-28}$

A possible explanation for the different effects between homodimers and heterodimers may be found in the BMP signaling pathway (summarized in Refs. ${ }^{29-31}$ ). The BMP signaling pathway converges at the receptor and intracellular signaling level. BMPs bind to two different types of serine/ threonine kinase receptors, known as type I and type II receptors (Fig. 1). The type I receptors are subdivided into three different activin receptor-like kinases (ALK), known as ALK-2, ALK-3, and ALK-6. Of these type I receptors, ALK-3 and ALK-6 have a high affinity for BMP-2/-4 group and a low affinity for the OP-1 group, ${ }^{32,33}$ whereas ALK-2 preferentially binds the OP-1 group. ${ }^{33-35}$ In contrast to the type I receptors, the three type II receptors (BMPR-II, ActR-IIA, and ActR-IIB) appear to bind most BMPs. Upon BMP binding, the receptors form multimers, most likely a tetramer consisting of two pairs of type I and type II receptors. ${ }^{36}$ This allows the activation of the type I receptor and subsequent intracellular signaling. The combination of ALK-3 or ALK-6 with ALK-2 type I receptor signaling was shown to be more potent in inducing transcriptional activation than signaling by either receptor alone. ${ }^{12}$ Binding of heterodimers may be more likely to induce such a combined receptor activation than homodimers. Another explanation for the enhanced activity of heterodimers may lie in differential Noggin antagonism of BMP action, which was shown to be decreased for heterodimers compared to homodimer signaling. ${ }^{37}$

\section{Transforming Growth Factor-Beta}

TGF- $\beta$ s are multifunctional growth factors with a broad range of biological activities in various cell types in many different tissues. Three isoforms of TGF- $\beta$ have been found in humans (TGF- $\beta 1$ through $-\beta 3$ ), which all consist of $25 \mathrm{kDa}$

Table 1. Combinations of Bone Morphogenetic Proteins

\begin{tabular}{|c|c|c|c|c|c|}
\hline Growth factors & Form (dose) & Setting & Outcome parameters & Effect & Ref \\
\hline BMP-2/BMP-7 & $\begin{array}{l}\text { Homodimers } \\
\qquad(100 \mu \mathrm{g} / 100 \mu \mathrm{g})\end{array}$ & $\begin{array}{l}\text { Tooth extraction defect } \\
\text { in primates }\end{array}$ & Bone area & n.s. ${ }^{a}$ & 23 \\
\hline BMP-4/BMP-7 & $\begin{array}{l}\text { Hetero- and } \\
\text { homodimers }\end{array}$ & $\begin{array}{l}\text { Critical-sized femoral } \\
\text { defect in rats }\end{array}$ & $\begin{array}{l}\text { Bone volume } \\
\text { Mechanical strength }\end{array}$ & $\begin{array}{l}\text { Homodimers n.s. } \\
\text { Heterodimers } \\
\text { synergistic }^{\mathrm{b}}\end{array}$ & 25 \\
\hline $\begin{array}{l}\text { Various BMP } \\
\text { combinations }\end{array}$ & $\begin{array}{l}\text { Hetero- and } \\
\text { homodimers }\end{array}$ & $\begin{array}{l}\text { Intramuscular implants } \\
\text { in mice/rats }\end{array}$ & Bone volume & $\begin{array}{l}\text { Homodimers n.s. } \\
\text { Heterodimers } \\
\text { synergistic }^{\mathrm{b}}\end{array}$ & 24 \\
\hline BMP-2/BMP-7 & Gene therapy & $\begin{array}{l}\text { Critical-sized calvarial } \\
\text { defect in mice }\end{array}$ & Bone volume & Additive effect ${ }^{c}$ & 26 \\
\hline BMP-2/BMP-7 & Gene therapy & $\begin{array}{l}\text { Subcutaneous implants } \\
\text { in mice }\end{array}$ & $\begin{array}{l}\text { AP activity } \\
\text { Calcium content } \\
\text { Phosphate content }\end{array}$ & Synergistic $^{c}$ & 27 \\
\hline BMP-2/BMP-7 & Gene therapy & $\begin{array}{l}\text { Posterolateral spinal } \\
\text { fusion model in rats }\end{array}$ & $\begin{array}{l}\text { Bone volume } \\
\text { AP activity } \\
\text { Osteocalcin }\end{array}$ & Synergistic $^{c}$ & 21 \\
\hline
\end{tabular}

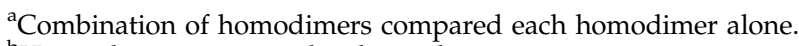

${ }^{\mathrm{b}}$ Heterodimers compared to homodimers.

${ }^{c}$ Adenovirus vectors encoding BMP-2 (AdBMP-2) and BMP-7 (AdBMP-7) compared to each vector alone

$\mathrm{AP}$, alkaline phosphatase; $\mathrm{BMP}$, bone morphogenetic protein; n.s., not significant. 

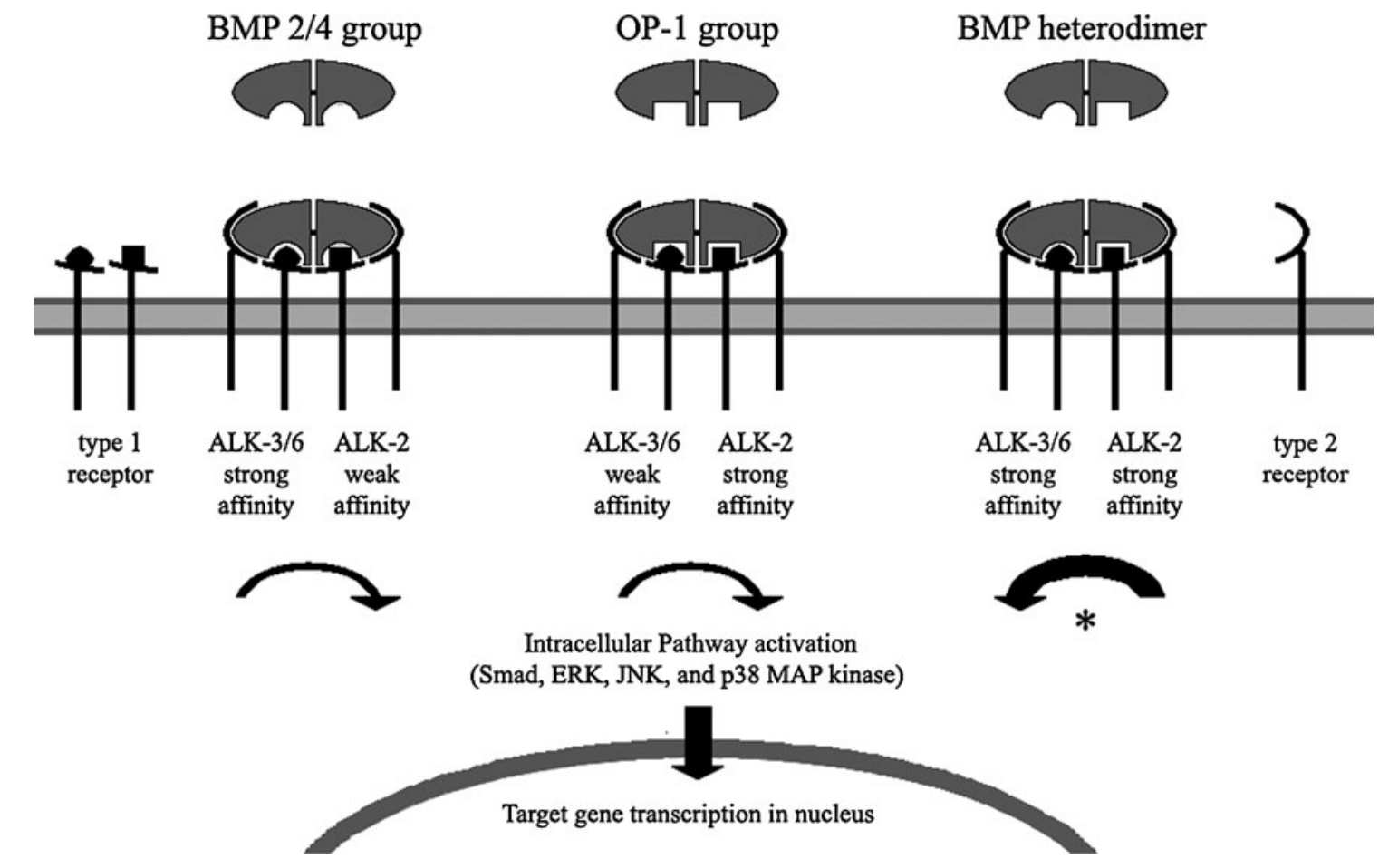

BMP heterodimer

FIG. 1. Signal transduction via BMP receptors. Upon BMP binding, the receptors most likely form tetramers consisting of two pairs of type I and type II receptors that subsequently activate the intracellular signaling pathways. Since the three type I receptors (ALK-2, ALK-3, and ALK-6) have different affinity for the various BMP molecules, the potency of the intracellular signaling activation varies between the different BMP-receptor complexes. The combination of ALK-3 or ALK-6 with ALK-2 type I receptor signaling was shown to be more potent in inducing transcriptional activation than signaling by either receptor alone $\left(^{*}\right)$. ALK, activin receptor-like kinase; BMP, bone morphogenetic protein.

homodimers sharing $60 \%-80 \%$ similarity in their amino acid sequence. TGF- $\beta$ is synthesized by many different cell types and is stored as an inactive complex with latency-associated peptide in the extracellular bone matrix. ${ }^{38}$ Another major source of this factor are platelets in the blood clot formed after a fracture. Release of the protein from the complex and subsequent induction of its bioactivity is tightly regulated and can occur through different mechanisms. ${ }^{39}$ In general, TGF- $\beta$ stimulates migration of osteoprogenitor cells and is a potent regulator of cell proliferation, cell differentiation, and extracellular matrix synthesis. ${ }^{40,41}$ Its use for bone regeneration has been evaluated in various experimental settings that show both stimulatory and inhibitory effects on bone formation. Overall, stimulatory effects on bone healing and bone formation predominate. ${ }^{40}$ Although no osteoinductive capacity is reported in rodent studies, intramuscular bone induction was found in a TGF- $\beta$-loaded collagenous matrix in primates. ${ }^{42,43}$

In several studies attempts were made to enhance bone regeneration by combining TGF- $\beta$ and BMPs (Table 2). ${ }^{42-50}$ To investigate a possible interaction between TGF- $\beta$ and BMP during bone induction, the combination was always compared to similar dosages of each of the individual growth factor. Despite the differences in experimental settings, isoforms used and delivery vehicles, most studies showed an additive or synergistic effect of the combination. Ectopic implantation studies in primates showed that TGF- $\beta$ enhanced BMP-7-induced bone formation in a doseresponsive manner. ${ }^{42,43}$ The largest synergistic effect was seen after coadministration of low TGF and BMP dosages combined with culture-expanded bone marrow stromal cells in RGD-modified alginate hydrogels. ${ }^{49}$

Although the exact molecular actions of the growth factor combinations are not fully understood, several effects have been proposed by which the different isoforms of TGF- $\beta$ synergize with BMPs. In the early phase after implantation, both growth factors can directly increase the local pool of osteoprogenitor cells by stimulating their migration. ${ }^{40}$ Since the circulation is one of the sources of osteoprogenitor cells during ectopic BMP-induced bone regeneration, ${ }^{51}$ cell recruitment may also be indirectly enhanced by their combined effect on angiogenesis. It has been suggested that TGF- $\beta 1$ and BMP-7 synergistically interact to enhance angiogenesis and vascular invasion since their coadministration increased vessel formation in a chick chorioallantoic membrane assay and type IV collagen expression in ectopic ossicles in primates. ${ }^{42,52}$ The mitogenic effect of TGF- $\beta$ may further increase the osteoprogenitor cell pool by stimulating cell proliferation. In vitro, this mitogenic effect did not modify the osteoinductive responsiveness of the cells to BMP. ${ }^{53}$

Apart from their combined effects on angiogenesis, cell recruitment and proliferation, TGF- $\beta$ and BMPs also interact during osteoblast differentiation (extensively reviewed by Janssens et $a l .{ }^{40}$ ). Despite the conflicting results of numerous in vitro experiments, it seems that TGF- $\beta 1$ may have stimulatory effects on osteoblast differentiation during the early stage and an inhibitory effect on differentiation and mineralization at later stages. This altered biological effect would 
Table 2. Combinations with Transforming Growth Factor-Beta

\begin{tabular}{|c|c|c|c|c|}
\hline Growth factor dose & Setting & Outcome parameters & Effect $^{\mathrm{a}}$ & Ref. \\
\hline $\begin{array}{l}15 \text { ng TGF- } \beta^{b} \\
2 \text { mg BMP-2 }\end{array}$ & $\begin{array}{l}\text { Intramuscular implants } \\
\text { in mice }\end{array}$ & Bone area & Synergistic & 48 \\
\hline $0.5-15 \mu \mathrm{g}$ TGF- $\beta 1$ & $\begin{array}{l}\text { Intramuscular implants } \\
\text { in primates }\end{array}$ & $\begin{array}{l}\text { Bone area } \\
\text { AP activity }\end{array}$ & Synergistic & 43 \\
\hline $\begin{array}{l}0.5-100 \mu \mathrm{g} \text { TGF- } \beta 1 \\
20-100 \mu \mathrm{g} \text { BMP-7 }\end{array}$ & $\begin{array}{l}\text { Intramuscular and calvarial } \\
\text { defect implants in primates }\end{array}$ & $\begin{array}{l}\text { Bone area } \\
\text { AP activity } \\
\text { Collagen expression }\end{array}$ & Synergistic & 42 \\
\hline $\begin{array}{l}10 \mathrm{ng} \text { TGF- } \beta 1 \\
15 \mathrm{mg} \mathrm{bBMP}\end{array}$ & $\begin{array}{l}\text { 3-mm segmental radial } \\
\text { defect in dogs }\end{array}$ & Bone area & Additive & 46 \\
\hline $\begin{array}{l}140 \text { ng TGF- } \beta 2 \\
\text { 25-400 ng bBMP } / \mathrm{mg} \\
\text { implant }\end{array}$ & $\begin{array}{l}\text { Subcutaneous implants } \\
\text { in rats }\end{array}$ & $\begin{array}{l}\text { Bone (semiquantitative) } \\
\text { AP activity }\end{array}$ & Synergistic & 44,45 \\
\hline $\begin{array}{l}12 \mu \mathrm{g} \text { TGF- } \beta 2 \\
25 \mu \mathrm{g} \text { BMP-2 }\end{array}$ & $\begin{array}{l}\text { Titanium implant } \\
\text { model in dogs }\end{array}$ & $\begin{array}{l}\text { Implant fixation } \\
\text { Bone area }\end{array}$ & $\begin{array}{l}\text { Additive (implant fixation) } \\
\text { Nonsignificant (bone area) }\end{array}$ & 50 \\
\hline $\begin{array}{l}20 \text { ng TGF- } \beta 3 \\
200 \text { ng BMP-2 }\end{array}$ & $\begin{array}{l}\text { Subcutaneous implants } \\
\text { in mice }\end{array}$ & Bone area & Synergistic & 49 \\
\hline $\begin{array}{l}0.2 \mu \mathrm{g} \text { TGF- } \beta 3 \\
2 \mu \mathrm{g} \text { BMP-2 }\end{array}$ & $\begin{array}{l}\text { Critical-sized femoral defect } \\
\text { in rats }\end{array}$ & $\begin{array}{l}\text { Bone volume } \\
\text { Mechanical strength }\end{array}$ & Nonsignificant & 47 \\
\hline
\end{tabular}

${ }^{a}$ Effect of combination of growth factors compared to TGF- $\beta$ and BMP alone.

${ }^{b}$ TGF- $\beta$ extracted from platelets by acid/ethanol procedure and chromatography.

${ }^{c} \mathrm{BMP}$ extracted and purified from bovine bone.

TGF- $\beta$, transforming growth factor-beta.

seem to be the result of crosstalk between the intracellular signaling pathways of BMP-2 and TGF- $\beta 1$. Although TGF- $\beta 1$ seems to inhibit matrix mineralization at later stages, the in vivo consequences of these inhibitory effects might be limited since expression of TGF- $\beta$ receptors is downregulated when cell differentiation progresses. This results in a decreased responsiveness to TGF- $\beta 1$ at later differentiation stages.

\section{Fibroblast Growth Factor}

FGFs are considered potent regulators of cell growth and wound healing. The FGF family consists of 25 members, which range in size from 17 to $34 \mathrm{kDa}$, share a $16 \%-65 \%$ similarity in amino acid sequence, and fall into different subgroups. ${ }^{54}$ In bone, they are produced by various cells, including osteoblasts, macrophages, and endothelial cells, and are stored in their active form in the extracellular bone matrix. When released or secreted, FGFs act in an autocrine and paracrine way as a mitogen on many cell types. In addition to their mitogenic effects, FGFs are involved in a number of other cellular processes, including angiogenesis, wound healing, and cell differentiation. During fracture healing, distinct groups of FGFs are differentially expressed, suggesting an active stagespecific role for FGF signaling during the repair process. ${ }^{55}$ In the early phase, FGF-1, -2 , and -5 genes are expressed, which is associated with a rapid increase in local cell population. ${ }^{55,56}$ At later stages, expression of other FGFs is upregulated, suggesting that these growth factors are involved in the regulation of chondrogenesis and osteogenesis. $^{55}$ The best studied family member on bone regeneration is FGF-2 (also known as bFGF). Although FGF-2 alone is not capable of inducing ectopic bone formation, it plays an important role in the regulation of normal bone healing. ${ }^{57}$ Exogenous FGF-2 enhances callus formation and stimulates bone healing in various orthopedic applications. ${ }^{58-64}$

In various studies FGF-2 or FGF-4 was combined with BMPs in an attempt to enhance bone regeneration and it was shown that the effects of FGF were time and dose dependent (Table 3). Using a local BMP-2 delivery vehicle in combination with subcutaneous FGF-4 injections for 3 consecutive days, FGF administration at an early stage after implantation (days 2-4) increased the amount of newly formed bone, whereas its administration at later time points (days $6-8$ or $9-11$ ) had no effect. ${ }^{65}$ When implanted in a delivery vehicle, low FGF dosages in combination with a single BMP dose synergistically enhanced BMP-induced bone formation; however, bone formation was inhibited by coadministration of high FGF dosages. ${ }^{66-69}$ The shift from an enhanced to an inhibitory effect occurred between $\sim 16$ and 2000 ng FGF per delivery vehicle.

So far, little is known about the mechanism underlying the dose- and time-dependent FGF effects. The time-dependent effect may suggest that FGF plays an important role in cell recruitment and expansion during the early phase of bone regeneration. This is also suggested in vitro, where successive exposure of mesenchymal stem cells to FGF followed by BMP was equally successful in inducing calcium deposition compared to combined growth factor exposure during the same period. ${ }^{70,71}$ In vivo, the combined angiogenic and migration effects of FGF could indirectly or directly enhance the recruitment of mesenchymal stem cells to the implantation site. ${ }^{52}$ Further, the mitogenic effect of FGF likely stimulates the proliferation of the local osteoprogenitor cells. BMPs can subsequently commit the enlarged osteoprogenitor cell pool toward the osteoblastic lineage, which ultimately results in the enhanced local bone formation.

Interestingly, in vitro, FGF-2/-9 were shown to stimulate mesenchymal stem cell proliferation and reversibly inhibit their differentiation in a dose-dependent manner. ${ }^{71-73}$ An inhibitory effect on the production of differentiation markers 
Table 3. Combinations with Fibroblast Growth Factor

\begin{tabular}{|c|c|c|c|c|}
\hline Growth factor dose & Setting & Outcome parameters & Effect ${ }^{\mathrm{a}}$ & Ref. \\
\hline 10 ng FGF-2 & \multirow{2}{*}{$\begin{array}{l}\text { Onlay of implants } \\
\text { on rabbit cranium }\end{array}$} & \multirow[t]{2}{*}{ Bone area } & Additive at 3 weeks & \multirow[t]{2}{*}{166} \\
\hline $1 \mu \mathrm{g} \mathrm{BMP-2}$ & & & Synergistic at 6 and 9 weeks & \\
\hline $0.8 \mu \mathrm{g}$ FGF-2 & \multirow{2}{*}{$\begin{array}{l}\text { Subcutaneous } \\
\text { implants in rats }\end{array}$} & AP activity & Synergistic on AP activity & \multirow[t]{2}{*}{167} \\
\hline $0.1 \mu \mathrm{g}$ BMP-2 & & $\begin{array}{l}\text { Calcium content } \\
\text { Collagen content }\end{array}$ & $\begin{array}{l}\text { and calcium content, inhibitory } \\
\text { on collagen content at } 2 \text { weeks, } \\
\text { nonsignificant at later times }\end{array}$ & \\
\hline $\begin{array}{l}\text { Cells exposed to } \\
2.5 / 50 \mathrm{ng} / \mathrm{mL} \\
\text { FGF-2/BMP-2 } \\
\text { for } 6 \text { days }\end{array}$ & $\begin{array}{l}\text { Implants with seeded } \\
\text { cells subcutaneous } \\
\text { in rats }\end{array}$ & $\begin{array}{l}\text { Semiquantitative } \\
\text { histologic score }\end{array}$ & Synergistic & 70 \\
\hline $0.1 \mu \mathrm{g}$ FGF-2 & \multirow{2}{*}{$\begin{array}{l}\text { Bone chamber model } \\
\text { in rabbits }\end{array}$} & Bone area & \multirow[t]{2}{*}{ Inhibitory } & \multirow[t]{2}{*}{168} \\
\hline $0.6 \mu \mathrm{g}$ BMP-2 & & Bone ingrowth & & \\
\hline $0.016-50 \mu \mathrm{g}$ FGF-2 & \multirow{2}{*}{$\begin{array}{l}\text { Intramuscular implants } \\
\text { in rats }\end{array}$} & Bone area & \multirow{2}{*}{$\begin{array}{l}\text { Synergistic at a dose } \leq 400 \mathrm{ng} \\
\text { inhibitory at a dose } \geq 2 \mu \mathrm{g}\end{array}$} & \multirow[t]{2}{*}{66} \\
\hline $2 \mu \mathrm{g} \mathrm{BMP-2}$ & & AP activity & & \\
\hline $0.001-5 \mu \mathrm{g}$ FGF-2 & \multirow{2}{*}{$\begin{array}{l}\text { Intramuscular implants } \\
\text { in mice }\end{array}$} & $\mathrm{BMD}$ & Synergistic at a dose $\leq 10 \mathrm{ng}$ & \multirow[t]{2}{*}{68} \\
\hline $5 \mu \mathrm{g} \mathrm{BMP-2}$ & & Bone area & inhibitory at a dose $\geq 100 \mathrm{ng}$ & \\
\hline $0.016-5 \mu \mathrm{g}$ FGF-2 & \multirow{2}{*}{$\begin{array}{l}\text { Intramuscular implants } \\
\text { in rats }\end{array}$} & $\mathrm{BMD}, \mathrm{BMC}$ & Synergistic at a dose $\leq 16 \mathrm{ng}$ & \multirow[t]{2}{*}{67} \\
\hline $2 \mu \mathrm{g} \mathrm{BMP-2}$ & & $\begin{array}{l}\text { Bone area } \\
\text { AP activity }\end{array}$ & inhibitory at a dose $\geq 80 \mathrm{ng}$ & \\
\hline $\begin{array}{l}0.2 \mathrm{mg} \text { FGF-2 } \\
1 \mathrm{mg} \mathrm{BMP-2}\end{array}$ & $\begin{array}{l}\text { Femoral osteotomy } \\
\text { in rabbits }\end{array}$ & Bone area & $\begin{array}{l}\text { Additive compared to } \\
\text { BMP-2 alone }\end{array}$ & 84 \\
\hline $\begin{array}{l}12.5 \mu \mathrm{g} \text { FGF-2 } \\
5 \mu \mathrm{g} \mathrm{BMP-2}\end{array}$ & $\begin{array}{l}\text { Implants seeded with cells } \\
\text { and cultured for } 1 \text { week } \\
\text { placed in rabbit spinal } \\
\text { fusion model }\end{array}$ & $\begin{array}{l}\text { Fusion determined } \\
\text { by radiographs } \\
\text { and palpation }\end{array}$ & Additive & 169 \\
\hline $\begin{array}{l}0.1 \mathrm{mg} \text { FGF-2 } / \mathrm{kg} / \text { day } \\
\text { for } 3 \text { days }\end{array}$ & $\begin{array}{l}\text { Subcutaneous BMP implants } \\
\text { in rats and three }\end{array}$ & Bone density & $\begin{array}{l}\text { Synergistic with FGF } \\
\text { administration }\end{array}$ & 65 \\
\hline [BMP] unknown & FGF injections & & at days $2-4$ & \\
\hline
\end{tabular}

${ }^{a}$ Effect of combination of growth factors compared to FGF and BMP alone.

${ }^{\mathrm{b} C o n t r o l ~ g r o u p ~ F G F ~ a l o n e ~ w a s ~ m i s s i n g . ~}$

FGF, fibroblast growth factor; BMD, bone mineral density; BMC, bone mineral contents.

like alkaline phosphatase activity and induction of mineralization were also seen in cultures containing FGF-2/-9 in combination with BMP-2 in a 1:5 ratio or with osteogenic medium. ${ }^{71,73,74}$ However, in cultures containing FGF-2 and BMP-2 at a ratio of $1: 10$ or higher, the combination had a stimulatory effect on the bone differentiation markers compared to BMP alone. ${ }^{70}$ These studies suggest a ratio-dependent FGF/BMP effect in which the mitogenic FGF stimulus overrules the BMP-induced osteogenic differentiation at high FGF concentrations. In vivo, the excessive amount of FGF at the time of BMP release might have inhibited bone induction.

In an attempt to further elucidate the mechanism behind the dose-related FGF effect, expression of genes associated with BMP signaling was studied in cells surrounding ectopically implanted FGF-2/BMP-2 delivery vehicles. ${ }^{68}$ Whereas BMP-2 alone induced an upregulation of ALK-3 and BMPR-II receptors, exposure to BMP-2 with FGF-2 resulted in an additional upregulation of ALK-6 receptor expression. ${ }^{68}$ In vitro, this FGF-enhanced ALK-6 expression augments BMP-induced Smad signaling and expression of alkaline phosphatase activity. ${ }^{75}$ Further, FGF-2 stimulated expression of Smad 6 (an inhibitory Smad) in a dosedependent manner, which may explain the inhibition of BMP-2-mediated differentiation at higher FGF concentrations. Although it is not known whether these changes in gene expression profiles are responsible for the in vivo physiological response, they clearly show a dose-dependent crosstalk between the FGF and BMP signaling pathways.

\section{Insulin-Like Growth Factor}

IGF-I and IGF-II are small single-chain polypeptides of $\sim 7.5 \mathrm{kDa}$ that play an important role in bone metabolism and are essential to skeletal growth and maintenance of bone mass. They are synthesized by multiple tissues and elicit their effects in an endocrine, paracrine, and autocrine way. The majority of IGFs exist in complexes, bound to one of the IGF-binding proteins that modulate their biological actions in a cell-specific manner. ${ }^{76}$ IGFs are the most abundant growth factors produced by bone cells and are stored at the highest concentration of all growth factors in the bone matrix. Although there is still debate about its exact role in bone cell proliferation and differentiation, IGF has an antiapoptotic effect on (pre)osteoblasts and enhances bone matrix synthesis. ${ }^{77}$ In vivo, systemic IGF infusion showed an increase in bone formation, bone volume, and/or bone turnover in animal models and clinical trials for osteoporosis. ${ }^{78}$ However, major drawbacks of systemic-free IGF administration are its side effects such as hypoglycemia, intracranial hypertension, headache, fatigue, and dyspnea. ${ }^{79}$ Consequently, localized IGF delivery was explored and showed to enhance bone formation without increasing circulating IGF-I levels. ${ }^{80,81}$ Although insulin can bind to the IGF receptor as well, higher concentrations will be required due to its lower affinity. Since this may cause hypoglycaemia, insulin will probably never be considered as a therapeutic agent for bone regeneration. 
Table 4. Combinations with Insulin-Like Growth Factor

\begin{tabular}{|c|c|c|c|c|}
\hline Growth factors & Setting & Outcome parameters & Effect $^{\mathrm{a}}$ & Ref. \\
\hline $\begin{array}{l}0.25 \mathrm{mg} \text { IGF-1 } \\
1 \mathrm{mg} \mathrm{BMP-2}\end{array}$ & Femoral osteotomy in rabbits & Bone area & $\begin{array}{l}\text { Additive compared } \\
\text { to BMP-2 alone }{ }^{\mathrm{b}}\end{array}$ & 84 \\
\hline $\begin{array}{l}10 \text { ng IGF-I } \\
25 \text { ng TGF- } \beta\end{array}$ & $\begin{array}{l}\text { Solution with growth factors } \\
\text { in a marginal femoral defect } \\
\text { in rats }\end{array}$ & Biomechanical test & Nonsignificant & 85 \\
\hline $\begin{array}{l}50 \mu \mathrm{g} \text { IGF-I } \\
10 \mu \mathrm{g} \text { TGF- } \beta 1\end{array}$ & $\begin{array}{l}\text { Coated titanium implants in a } \\
\text { midshaft tibia fracture in rats }\end{array}$ & $\begin{array}{l}\text { Biomechanical test } \\
\text { Callus formation }\end{array}$ & Additive/synergistic & 88 \\
\hline $\begin{array}{l}25 \mathrm{ng} \text { IGF-1 } \\
0.1 \mu \mathrm{g} \text { TGF- } \beta 1\end{array}$ & $\begin{array}{l}\text { Gelatin hydrogel in a segmental } \\
\text { tibia defect in rats }\end{array}$ & Bone formation (X-ray) & Nonsignificant & 86 \\
\hline $\begin{array}{l}25 \mathrm{ng} \text { IGF-1 } \\
0.1 \mu \mathrm{g} \text { TGF- } \beta 1\end{array}$ & $\begin{array}{l}\text { Gelatin hydrogel in a marginal } \\
\text { mandibular defect in rats }\end{array}$ & Bone formation (X-ray) & Nonsignificant & 87 \\
\hline
\end{tabular}

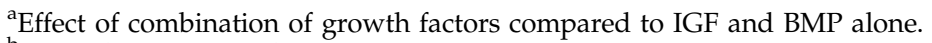

${ }^{\mathrm{b}}$ Control group IGF alone was missing.

IGF, insulin-like growth factor.

A limited number of studies have investigated the effect of combined IGF-I and BMP addition on in vitro and in vivo osteogenesis. In vitro, sequential exposure to BMP-2 followed by IGF-I led to synergistically enhanced mesenchymal cell proliferation and alkaline phosphatase activity. ${ }^{82}$ Similar effects were seen after exogenous BMP-7 and IGF-I administration or cotransfection of both genes in fetal calvarial cell cultures. ${ }^{83}$ Both studies suggest that IGF-I enhances the mitogenic action as well as the differentiation activity of BMPs. In an in vivo bone-implant integration model, combined delivery of IGF-I and BMP-2 from coated titanium screws significantly improved bone formation compared to BMP-2 alone (Table 4$).^{84}$ Thus, the IGF/BMP combination seems to enhance both in vitro and in vivo osteogenesis.

The combination of IGF and TGF- $\beta$ has been studied more extensively. Unfortunately, few studies compared the growth factor combination versus single IGF and TGF- $\beta$ controls and their experimental setup varied greatly, in particular with respect to dose and delivery vehicle (Table 4). ${ }^{85-88}$ Compared to TGF- $\beta$ alone, nanogram dosages of the IGF/TGF- $\beta$ combination in solution or released from gelatin hydrogels did not result in significantly enhanced mechanical properties or bone formation in rat marginal cortical defects, tibial defects, and mandibular defects, but the release of micrograms of the growth factor combination from a coated titanium implant enhanced the mechanical properties and callus formation in a rat tibial fracture model (Table 4).

Although only the latter in vivo study showed enhanced effects of the IGF/TGF- $\beta$ combination over TGF- $\beta$ alone, in vitro studies clearly suggest an interaction of both growth factors in regulation of bone formation. Synthesis of IGFs and IGF-binding proteins by osteoblasts is regulated by various growth factors, including TGF- $\beta{ }^{89,90}$ Further, exogenously administered combinations of IGF-I and TGF- $\beta$ synergistically enhanced cell proliferation and matrix synthesis in osteoblast cultures. ${ }^{91-94}$ A similar synergistic effect of IGF-I and FGF was seen on cell proliferation and matrix synthesis in osteoblast cultures. ${ }^{91,92}$ Unfortunately, no studies have been performed to investigate the effect of an IGF/ FGF combination on in vivo bone regeneration.

\section{Vascular Endothelial Growth Factor}

VEGF is considered one of the key regulators of angiogenesis during bone formation. ${ }^{95}$ The biologically active

Table 5. Combinations with Vascular Endothelial Growth Factor

\begin{tabular}{|c|c|c|c|c|}
\hline Growth factor dose & Setting & Outcome parameters & Effect $^{\mathrm{a}}$ & Ref. \\
\hline $\begin{array}{l}\text { Cells expressing VEGF } \\
\text { or BMP-2 }\end{array}$ & IM and CD in mice & Bone area & $\begin{array}{l}\text { Synergistic (IM) } \\
\text { Additive (CD) }\end{array}$ & 101 \\
\hline $\begin{array}{l}\text { Cells expressing VEGF } \\
\text { or BMP-2 }\end{array}$ & IM in mice & Bone area & $\begin{array}{l}\text { Synergistic at } 4 \text { weeks } \\
\text { Nonsignificant at } 8 \text { weeks }\end{array}$ & 108 \\
\hline $\begin{array}{l}2 \mu \mathrm{g} \text { VEGF } \\
6.6 \mu \mathrm{g} \mathrm{BMP}-2\end{array}$ & $\begin{array}{l}\mathrm{SC} \text { and critical-sized FD } \\
\text { in rats }\end{array}$ & Bone volume & $\begin{array}{l}\text { Additive (SC) } \\
\text { Nonsignificant (FD) }\end{array}$ & 110 \\
\hline $\begin{array}{l}12 \mu \mathrm{g} \text { VEGF } \\
2 \mu \mathrm{g} \text { BMP-2 }\end{array}$ & Cranial defect in rats & Bone volume & $\begin{array}{l}\text { Synergistic at } 4 \text { weeks } \\
\text { Nonsignificant at } 12 \text { weeks }\end{array}$ & 111 \\
\hline $\begin{array}{l}\text { Cells expressing VEGF } \\
\text { or BMP-4 }\end{array}$ & IM and CD in mice & Bone area & $\begin{array}{l}\text { Synergistic (IM) } \\
\text { Additive (CD) }\end{array}$ & 107 \\
\hline $\begin{array}{l}3 \mu \mathrm{g} \text { VEGF } \\
\text { BMP-4 plasmid }\end{array}$ & SC implants in mice & $\begin{array}{l}\text { Bone area } \\
\text { Bone mineral density } \\
\text { Bone mineral content }\end{array}$ & Additive & 109 \\
\hline
\end{tabular}

${ }^{a}$ Effect of combination of growth factors compared to VEGF and BMP alone.

CD, calcarial defect; FD, femoral defect; IM, Intramuscular implants; SC, subcutaneous; VEGF, vascular endothelial growth factor. 
form of VEGF, also referred to as VEGF-A, is a dimeric protein that may consist of different splice variants (121-206 amino-acids) of a single gene. Most cell types produce several VEGF forms simultaneously and their expression can be enhanced by hypoxia or other cytokines. In vivo, VEGF induces angiogenesis as well as permeabilization of capillaries. ${ }^{96,97}$ During bone repair, these newly formed vessels and vascular changes are crucial for nutrient supply, transport of macromolecules, and invading cells. The important role of VEGF during bone regeneration has been shown in various experimental models, demonstrating stimulation or disruption of the normal bone regeneration process in response to VEGF administration or inhibition, respectively. ${ }^{98-101}$

Several in vitro studies suggest a BMP/VEGF-regulated coupling between osteogenesis and angiogenesis through reciprocal signaling. Cocultures demonstrated that osteoblastlike cells stimulated the proliferation of endothelial cells by production of VEGF, whereas endothelial cells stimulated the differentiation of osteoprogenitor cells by production of BMP-2. ${ }^{102,103}$ Further, BMP-induced differentiation of preosteoblast-like cells enhanced endogenous production of VEGF. ${ }^{104-106}$ These studies show the importance of angiogenesis during osteogenesis and emphasize the possible benefits of combining VEGF and BMPs for bone regeneration.

So far, VEGF has only been combined with BMPs in an attempt to enhance bone regeneration. The combined implantation of VEGF-expressing cells with BMP-2 or BMP-4expressing cells synergistically enhanced bone formation at an ectopic implantation site (Table 5). ${ }^{101,107,108}$ This effect on bone regeneration was dependent on the amount of cells applied and the ratio of VEGF-/BMP-expressing cells. Interestingly, coimplantation of cells expressing the VEGF-antagonist soluble Flt1 had an inhibitory effect on bone induction by BMP-2- or BMP-4-expressing cells. ${ }^{101,107}$ The enhancement of BMP-induced osteogenesis by VEGF was further investigated using local delivery vehicles releasing recombinant VEGF in combination with a BMP-4 plasmid or recombinant BMP$2{ }^{109-111}$ Although these studies showed enhancement of BMP-induced bone formation by VEGF, the effects with recombinant growth factor(s) were less pronounced compared to the studies using ex vivo transduced cells.

Several mechanisms could be responsible for the enhanced BMP-2-induced bone formation by VEGF. In addition to $\mathrm{BMP}$, VEGF may stimulate the recruitment of mesenchymal stem cells. ${ }^{112,113}$ Further, VEGF-induced vascular changes (e.g., increased vascular support network and vascular permeability) could enhance this cell recruitment. In combination with BMP-transduced cells, the VEGF-induced angiogenesis could also have resulted in an increased survival of BMP-expressing cells. Such a larger pool of BMPexpressing cells could have resulted in higher local dose of the osteoinductive factor and a subsequent larger amount of bone as a result of the dose-response relation between BMP and bone formation.

\section{Platelet-Derived Growth Factor}

PDGF is considered one of the key regulators of general tissue repair. ${ }^{114}$ Its family consists of dimeric proteins of $\sim 30 \mathrm{kDa}$ composed of disulfide-linked polypeptides encoded by four different genes (PDGF-A, -B, -C, and -D) which form homodimers (PDGF-AA, -BB, -CC, and -DD) and heterodimers (PDGF-AB). During the early phase of wound healing, platelets are the major source of PDGF. After injury and hemorrhage, platelets aggregate and release cytokine-loaded granules containing various amounts of PDGFs. Upon release, PDGFs stimulate the recruitment of neutrophils, macrophages, and mesenchymal cells, which then serve as an ongoing source of PDGFs during the healing process. PDGF also enhances proliferation of various bone cell types and enhances angiogenesis by its induction of sprouting from adjacent blood vessels and expression of VEGF. Although both PDGF and VEGF stimulate angiogenesis, PDGF stimulates the migration of a population of mesenchymal cells that appears to be different from those stimulated by VEGF. ${ }^{115,116}$ Apart from its positive effect on soft tissue healing, the therapeutic potential of PDGF was also demonstrated in various animal models for skeletal reconstruction. ${ }^{114}$

The effect of various dosages of PDGF-BB was studied in combination with BMPs in a collagen matrix in a craniotomy defect (Table 6). ${ }^{117}$ Whereas BMPs caused a dose-dependent increase in radiopacity and bone area in the defect, BMPinduced bone formation was inhibited by PDGF-BB dosages between 20 and $200 \mu \mathrm{g}$. Also in combination with demineralized bone matrix, which contains various growth factors, including BMPs, PDGF showed a similar inhibitory effect. ${ }^{118}$ This inhibitory effect of PDGF on BMP-induced or

Table 6. Combinations with Platelet-Derived Growth Factor

\begin{tabular}{|c|c|c|c|c|}
\hline Growth factors & Setting & Outcome parameters & Effect $^{\mathrm{a}}$ & Ref. \\
\hline $\begin{array}{l}20-100 \mu \mathrm{g} \text { PDGF-BB } \\
30-150 \mu \mathrm{g} \text { BMP }\end{array}$ & Cranial defect in rats & Radioopacity and bone area & Inhibitory & 117 \\
\hline $\begin{array}{l}50 \mu \mathrm{L} \mathrm{PRP} \mathrm{P}^{\mathrm{b}} \\
200 \mathrm{ng} \mathrm{BMP}-2^{-2}\end{array}$ & Cranial defect in rats & $\begin{array}{l}\text { Bone mineral density } \\
\text { Bone mineral content }\end{array}$ & Synergistic & 134 \\
\hline $\begin{array}{l}100 \mu \mathrm{L} \text { PRP } \\
15 \mu \mathrm{g} \text { BMP-2 }\end{array}$ & Cranial defect in rabbits & Bone area & Nonsignificant & 135 \\
\hline $\begin{array}{l}10 \mu \mathrm{g} \text { PDGF-BB } \\
10 \mu \mathrm{g} \text { IGF-I }\end{array}$ & Periodontal defect in primates & $\begin{array}{l}\text { Bone area } \\
\text { New tooth attachments }\end{array}$ & Nonsignificant & 129 \\
\hline $\begin{array}{l}6 \mu \mathrm{g} \text { PDGF-BB } \\
6 \mu \mathrm{g} \text { IGF-I }\end{array}$ & Partial-thickness tibial defect in pigs & Callus formation & Synergistic $^{c}$ & 123 \\
\hline
\end{tabular}

${ }^{a}$ Effect of combination compared to PDGF or PRP and BMP alone.

${ }^{b}$ Platelet concentrate containing various growth factors, including PDGF, TGF- $\beta$, IGF-I, and VEGF.

${ }^{\mathrm{C} C}$ Compared to intraanimal controls, however, absolute IGF-I values were higher or equal compared to combination group.

PDGF, platelet-derived growth factor; PRP, platelet-rich plasma. 
demineralized bone matrix-induced bone formation could be the result of its inhibitory effect on osteoprogenitor differentiation as indicated by its in vivo inhibitory effect on the bone matrix apposition rate and in vitro inhibition of the osteoblast phenotypic markers osteocalcin and alkaline phosphatase. ${ }^{119-122}$ As PDGF stimulates active bone resorption, the inhibitory effect could also be attributed to a reduction of available surface for bone formation as the surface is eroded by the increased number of osteoclasts. ${ }^{120}$

The effect of the PDGF/IGF combination has been studied in a partial-thickness tibial defects in pigs. ${ }^{123}$ Comparison of growth factor-treated defects and empty intraanimal control defects showed that the combination of PDGF/IGF-I increased callus area and thickness, whereas neither of the growth factors alone enhanced regeneration. However, interpretation of these data remains difficult since the absolute callus area and thickness of implants containing IGF-I alone were equal or higher compared to the PDGF/IGF-I combination. In contrast to this ambiguous in vivo effect, in vitro studies did show enhanced effects of the PDGF/IGF combination. In vitro, increased proliferation of several bone cell types, deposition of collagen, and formation of bone matrix was found, compared to the same amount of either of the growth factors individually. ${ }^{91,94}$ Further studies are required to characterize the interaction of these growth factors in bone regeneration.

The combination of PDGF and IGF has been studied more extensively in periodontal regeneration. Several in vivo studies showed the formation of substantial amounts of new bone, cementum, and periodontal ligament by a combination of PDGF-BB and IGF-I. ${ }^{124-127}$ In a clinical trial, the local application of a high dose $(150 \mu \mathrm{g} / \mathrm{mL})$ of $\mathrm{rhPDGF} / \mathrm{rhIGF}-\mathrm{I}$ significantly increased alveolar bone formation compared to controls without growth factor. ${ }^{128}$ However, in only one study the PDGF/IGF-I combination was compared to individual growth factor controls. ${ }^{129}$ In this primate model, the tested dose of IGF-I alone had no significant effect on bone formation and the formation of new attachments between the tooth and periodontal bone. Although the PDGF/ IGF-I combination significantly enhanced bone and new attachment formation compared to the delivery vehicle alone, no significant differences were seen compared to PDGF alone.

A substance that typically contains PDGF in addition to several other growth factors is platelet-rich plasma (PRP) or platelet gel. The platelets in PRP contain several growth factors, including PDGF, TGF- $\beta$, IGF-I, and VEGF, that are released upon their activation. Since this event also occurs after normal bone injury, the concept to enhance bone regeneration with autologous PRP is obvious. So far, the effects of PRP in various clinical and animal models of bone regeneration are ambiguous, with both enhancement of bone regeneration and lack of additional effects reported. ${ }^{130-133}$ In combination with BMP-2, human PRP improved angiogenesis and resulted in enhanced bone healing compared to BMP-2 alone in a rat cranial defect. ${ }^{134}$ However, no statistically significant differences of platelet growth factor release was seen after combined implantation of rabbit PRP/BMP-2 gels compared to fibrin/BMP-2 gels in rabbit cranial defects. ${ }^{135}$ Moreover, in a clinical trial, the combination of PRP and BMP has shown to be even less effective than BMPs alone. ${ }^{136}$ In addition to the variation in experimental setups between these studies, growth factor concentrations in PRP are known to be variable between species and individuals, ${ }^{137}$ all adding to the confusion around effectivity of PRP and combinations with BMPs.

\section{Cytokines}

The term cytokine encompasses a large and diverse family of proteins that historically refers to the immunomodulating agents (ILs, interferons, tumor necrosis factors, etc.). However, as more was learned about them, it appeared that these molecules play an essential role in the complex crosstalk between the immune and skeletal system. Although the mechanisms are still poorly understood, it has become apparent that many cytokines are involved in bone metabolism and are able to stimulate or inhibit the formation and function of osteoblasts, osteoclasts, or their precursor cells. ${ }^{138-141}$

Despite the large number of available cytokines, only IL-11 has been studied in combination with BMP-2 in bone regeneration models (Table 7). IL-11 is produced by various cells and has several biological activities, including roles in hematopoiesis, immune responses, and bone metabolism. ${ }^{142,143}$ In vitro, IL-11 enhances osteoclast formation and bone resorption, but also stimulates expression of osteoblastic markers in mesenchymal progenitor cells. ${ }^{144-146}$ During osteogenesis, IL-11 synergizes with BMP-2 in a dose-dependent fashion to enhance the in vitro osteoblastic differentiation of progenitor cells. ${ }^{146}$ Although the mechanical properties of the formed bone were not significantly different compared to BMP-2 alone, a similar synergistic increase in bone formation rate was seen after combined implantation of IL-11 and BMP-2 in a rat ectopic and rabbit segmental bone defect

Table 7. Combinations with Cytokines

\begin{tabular}{llll}
\hline Growth factors & \multicolumn{1}{c}{ Setting } & Outcome parameters & Effect $^{\mathrm{a}}$ \\
\hline $\begin{array}{l}20-200 \mu \mathrm{g} \text { IL-11 } \\
6 \mu \mathrm{g} \text { BMP-2 }\end{array}$ & SC implants in rats & Calcium content & Synergistic \\
$200 \mu \mathrm{g} \mathrm{IL-11}$ & Segmental bone defect & Bone volume \\
$1 \mathrm{mg} \mathrm{BMP-2}$ & in rabbits & Mechanical strength & $\begin{array}{c}\text { Synergistic } \\
\text { (bone volume) } \\
\text { Nonsignificant } \\
\text { (mechanical strength) }\end{array}$ \\
\hline
\end{tabular}

${ }^{a}$ Effect of combination compared to IL-11 and BMP alone.

IL, interleukin. 
Table 8. Combinations with Systemically Administered Hormones

\begin{tabular}{|c|c|c|c|c|}
\hline Growth factor dose & Setting & Outcome parameters & Effect ${ }^{\mathrm{a}}$ & Ref. \\
\hline $\begin{array}{l}20 \text { and } 40 \mu \mathrm{g} / \mathrm{kg} / \text { day PTH } \\
5 \mu \mathrm{g} \text { BMP-2 }\end{array}$ & SC BMP-2 implants in rats & $\begin{array}{l}\text { AP activity } \\
\text { Calcium content }\end{array}$ & Synergistic & 156 \\
\hline $\begin{array}{l}10 \mu \mathrm{g} / \mathrm{kg} / \text { day PTH } \\
5 \mu \mathrm{g} \text { BMP-2 }\end{array}$ & SC BMP-2 implants in mice & $\begin{array}{l}\text { Bone mineral density } \\
\text { Calcium content }\end{array}$ & Synergistic & 157 \\
\hline $\begin{array}{l}10 \mu \mathrm{g} / \mathrm{kg} / \text { day } \mathrm{PTH} \\
6.5 \mu \mathrm{g} \mathrm{BMP}-2\end{array}$ & $\begin{array}{l}\text { BMP- } 2 \text { implants in SC and FD } \\
\text { in rats }\end{array}$ & $\begin{array}{l}\text { Bone mineral density } \\
\text { Bone volume }\end{array}$ & $\begin{array}{l}\text { Synergistic (SC) } \\
\text { Additive (FD) }\end{array}$ & 158 \\
\hline $\begin{array}{l}10 \mu \mathrm{g} / \mathrm{kg} / \text { day PTH } \\
200 \mu \mathrm{g} \text { BMP-7 }\end{array}$ & $\begin{array}{l}\text { BMP-7 implants in a partial-thickness } \\
\text { tibial defect in rabbits }\end{array}$ & $\begin{array}{l}\text { Bone mineral content } \\
\text { Bone volume } \\
\text { Mechanical strength }\end{array}$ & Nonsignificant & 159 \\
\hline $\begin{array}{l}0.2 \text { and } 0.4 \mu \mathrm{g} / \mathrm{kg} / \text { day } \mathrm{PGE}_{2} \\
5 \mu \mathrm{g} \text { BMP- } 2\end{array}$ & SC BMP-2 implants in rats & $\begin{array}{l}\text { AP activity } \\
\text { Calcium content }\end{array}$ & Synergistic & 156 \\
\hline $\begin{array}{l}50 \text { and } 100 \mathrm{ng} / \mathrm{kg} / \text { day } \mathrm{VitD}_{3} \\
5 \mu \mathrm{g} \text { BMP-2 }\end{array}$ & SC BMP-2 implants in rats & $\begin{array}{l}\text { AP activity } \\
\text { Calcium content }\end{array}$ & Synergistic & 156 \\
\hline
\end{tabular}

${ }^{a}$ Effect of combination compared to the hormone and BMP alone.

$\mathrm{PTH}$, parathyroid hormone; VitD 3 , 1-alpha,25-dihydroxyvitamin D3.

model. ${ }^{147,148}$ Overall, these results show that IL-11 actions predominantly enhance BMP-2-induced bone formation.

\section{Systemic Regulators}

In contrast to the local application of the previously mentioned growth factors and cytokines, some systemically administered hormones also enhance bone formation. Of particular interest is $\mathrm{PTH}$, a major systemic regulator of bone metabolism. It is secreted from the parathyroid glands and travels through the bloodstream to act upon bone. Whereas continuous PTH infusion causes the bone disease osteitis fibrosa, its intermittent subcutaneous administration enhances bone formation. ${ }^{149,150}$ The anabolic effect of intermittent PTH on bone has made it an effective treatment for osteoporosis in humans, where it was shown to increase bone mass and reduce fracture rate. ${ }^{151}$ So far, the mechanism behind this dual effect is still not completely understood. It has been suggested that PTH-induced stimulation of bone formation is due to an increase in osteoblast number. This increase in osteoblast number is not dependent on osteoblastogenesis, rather is the result of activation of existing bone-lining cells that undergo hypertrophy and resume matrix synthesis. ${ }^{149,152-155}$ Another proposed method for its effect is the inhibition of osteoblast apoptosis. ${ }^{149,153}$

Since PTH acts upon cells committed to the osteoblastic lineage, it has been combined with osteoinductive BMPs (Table 8). Ectopically, systemic PTH treatment increased the local BMP-2-induced bone formation and reversed the agerelated decrease in osteoinductive potential of BMP-2. ${ }^{156-158}$ Although systemic PTH treatment enhanced healing of a partial-thickness tibial defect, no significant effect of BMP-7 and no synergistic effect of the PTH/BMP-7 combination were seen. ${ }^{159}$ In a critical-sized femoral defect, the effects of BMP-2 and PTH alone were opposite and their combination synergistically enhanced bone formation. ${ }^{158}$ The discrepancy between these studies may be due to the different orthotopic models. In the partial-thickness defect, endogenous production of BMPs was sufficient to heal the defect. Consequently, PTH enhanced this endogenously induced bone formation and addition of BMP-7 had no significant effect. ${ }^{159}$ The interference of this local autoinduction was less in the critical- sized defects where no spontaneous healing was seen in empty defects and bone formation was significantly enhanced by BMP-2. ${ }^{158}$

Apart from the PTH/BMP-2 combination, BMP-2 has also been combined with systemic administration of prostaglandin $\mathrm{E}_{2}$ and [1,25-dihydroxy]vitamin $\mathrm{D}_{3} .{ }^{156}$ In bone, the anabolic actions of systemically administered prostaglandin $\mathrm{E}_{2}$ increases bone formation and bone mass. ${ }^{160,161}$ In combination with BMP-2, a low dose of prostaglandin $\mathrm{E}_{2}$ significantly increased alkaline phosphatase activity and calcium content of ectopic implants in rats.

In addition to $\mathrm{PTH}$, vitamin $\mathrm{D}$ is an important regulator of bone mineral homeostasis. It plays an important role in osteoblast/osteoclast communication by stimulating the production of receptor activator of nuclear factor- $\kappa \mathrm{B}$ ligand (RANKL) by osteoblasts, which enhances the recruitment and activation of osteoclasts. ${ }^{162}$ In addition to the stimulation of osteoblastic activity, it also inhibits osteoblast apoptosis. Despite its complex actions on both osteoblast and osteoclast activity, vitamin D treatment of osteoporotic patients resulted in a modest enhancement of bone mineral density. ${ }^{163-165}$ Systemic administration of vitamin D3 significantly increased alkaline phosphatase activity and calcium content of ectopic BMP-2-loaded implants. ${ }^{156}$ So far, the mechanism behind this effect is not known and further studies are required to characterize this vitamin $\mathrm{D}_{3}-\mathrm{BMP}-2$ interaction.

\section{Summary and Future Directions}

Ever since the discovery of the autoinductive capacity of bone by bioactive peptides, researchers have attempted to enhance bone regeneration by modulating the cellular behavior using growth factors, cytokines, and hormones. Although their exact role during the regeneration process has not been fully defined, many of these molecules are able to enhance bone formation with varying potency and efficacy. As shown by the studies summarized in this review, many of these growth factors interact during bone formation. Depending on the combination of growth factors, their routes of delivery, the dosage used, and the animal model, this interaction could result in an enhancement or inhibition of bone formation compared to the individual growth factors. 
Synergistic effects on bone formation are seen for most combinations, which in the case of fabricated BMP heterodimers even resulted in a 20-fold increase in bone formation compared to homodimers. Since these translational studies are performed to develop new therapies for bone regeneration, growth factor combinations with in vitro inhibitory effects are unlikely studied in translational bone regeneration studies. This may be the reason that only few studies with nonsignificant or inhibitory effects of combination therapies could be found.

To date, the fragmentary results on combinations of usually two growth factors with a limited number of growth factor concentrations and timing suggest that this is a rather understudied area of investigation in bone regeneration, despite its tremendous potential and virtually endless possible combinations. It is recommended that future studies address these challenges by systematically analyzing the many possibilities and that new, high-throughput screening techniques will be required to achieve this. Overall, this review shows we are only beginning to understand the possibilities of applying multiple growth factors and cytokines in vivo, the signaling pathways involved, and their convergence points.

Bone regeneration based on the delivery of bioactive molecules is a promising strategy that could revolutionize the way bone grafting procedures are performed in orthopedics, neurosurgery, and dentistry. Despite the success of current single-drug treatments, our knowledge of the bone regeneration process and growth factor interactions is still limited. Therefore, further molecular, cellular, and translational studies are required to obtain a better understanding of the actions and interactions of the different regulators of the regeneration process. In addition, the challenge in translational research will be to improve local delivery vehicles and their pharmacokinetic profiles. So far, many of the growth factor combinations have been released from relatively simple delivery vehicles with unknown pharmacokinetic profiles. New delivery vehicles with adjustable release profiles would help identify the optimal amounts, ratio, timing, and release sequence of these regulators to optimize the bone regeneration process and ensure consistent success in clinical applications.

\section{Acknowledgments}

The authors wish to thank The Netherlands Organization for Health Research and Development ZonMW (Agiko 92003-325); the Smart Mix Program of the Netherlands Ministry of Economic Affairs; and the Netherlands Ministry of Education, Culture and Science for their financial support.

\section{Disclosure Statement}

No competing financial interests exist

\section{References}

1. Giannoudis, P.V., Dinopoulos, H., and Tsiridis, E. Bone substitutes: an update. Injury 36 Suppl 3, S20, 2005.

2. Buck, B.E., Malinin, T.I., and Brown, M.D. Bone transplantation and human immunodeficiency virus. An estimate of risk of acquired immunodeficiency syndrome (AIDS). Clin Orthop Relat Res 240, 129, 1989.
3. Younger, E.M., and Chapman, M.W. Morbidity at bone graft donor sites. J Orthop Trauma 3, 192, 1989.

4. Arrington, E.D., Smith, W.J., Chambers, H.G., Bucknell, A.L., and Davino, N.A. Complications of iliac crest bone graft harvesting. Clin Orthop Relat Res 329, 300, 1996.

5. Norman-Taylor, F.H., and Villar, R.N. Bone allograft: a cause for concern? J Bone Joint Surg Br 79, 178, 1997.

6. Silber, J.S., Anderson, D.G., Daffner, S.D., Brislin, B.T., Leland, J.M., Hilibrand, A.S., Vaccaro, A.R., and Albert, T.J. Donor site morbidity after anterior iliac crest bone harvest for single-level anterior cervical discectomy and fusion. Spine 28, 134, 2003.

7. Urist, M.R. Bone: formation by autoinduction. Science 150, 893, 1965.

8. Urist, M.R., Iwata, H., Ceccotti, P.L., Dorfman, R.L., Boyd, S.D., McDowell, R.M., and Chien, C. Bone morphogenesis in implants of insoluble bone gelatin. Proc Natl Acad Sci U S A 70, 3511, 1973.

9. Riley, E.H., Lane, J.M., Urist, M.R., Lyons, K.M., and Lieberman, J.R. Bone morphogenetic protein-2: biology and applications. Clin Orthop Relat Res 324, 39, 1996.

10. Rengachary, S.S. Bone morphogenetic proteins: basic concepts. Neurosurg Focus 13, e2, 2002.

11. Wozney, J.M. Overview of bone morphogenetic proteins. Spine 27, S2, 2002.

12. Aoki, H., Fujii, M., Imamura, T., Yagi, K., Takehara, K., Kato, M., and Miyazono, K. Synergistic effects of different bone morphogenetic protein type I receptors on alkaline phosphatase induction. J Cell Sci 114, 1483, 2001.

13. Hazama, M., Aono, A., Ueno, N., and Fujisawa, Y. Efficient expression of a heterodimer of bone morphogenetic protein subunits using a baculovirus expression system. Biochem Biophys Res Commun 209, 859, 1995.

14. Sampath, T.K., Coughlin, J.E., Whetstone, R.M., Banach, D., Corbett, C., Ridge, R.J., Ozkaynak, E., Oppermann, H., and Rueger, D.C. Bovine osteogenic protein is composed of dimers of OP-1 and BMP-2A, two members of the transforming growth factor-beta superfamily. J Biol Chem 265, 13198, 1990.

15. Canalis, E., Economides, A.N., and Gazzerro, E. Bone morphogenetic proteins, their antagonists, and the skeleton. Endocr Rev 24, 218, 2003.

16. Wang, E.A., Rosen, V., Cordes, P., Hewick, R.M., Kriz, M.J., Luxenberg, D.P., Sibley, B.S., and Wozney, J.M. Purification and characterization of other distinct bone-inducing factors. Proc Natl Acad Sci U S A 85, 9484, 1988.

17. Cheng, H., Jiang, W., Phillips, F.M., Haydon, R.C., Peng, Y., Zhou, L., Luu, H.H., An, N., Breyer, B., Vanichakarn, P., Szatkowski, J.P., Park, J.Y., and He, T.C. Osteogenic activity of the fourteen types of human bone morphogenetic proteins (BMPs). J Bone Joint Surg Am 85-A, 1544, 2003.

18. Luu, H.H., Song, W.X., Luo, X., Manning, D., Luo, J., Deng, Z.L., Sharff, K.A., Montag, A.G., Haydon, R.C., and He, T.C. Distinct roles of bone morphogenetic proteins in osteogenic differentiation of mesenchymal stem cells. J Orthop Res 25, 665, 2007.

19. Wang, E.A., Rosen, V., D'Alessandro, J.S., Bauduy, M., Cordes, P., Harada, T., Israel, D.I., Hewick, R.M., Kerns, K.M., LaPan, P., et al. Recombinant human bone morphogenetic protein induces bone formation. Proc Natl Acad Sci U S A 87, 2220, 1990.

20. Niikura, T., Hak, D.J., and Reddi, A.H. Global gene profiling reveals a downregulation of BMP gene expression in 
experimental atrophic nonunions compared to standard healing fractures. J Orthop Res 24, 1463, 2006.

21. Zhu, W., Rawlins, B.A., Boachie-Adjei, O., Myers, E.R., Arimizu, J., Choi, E., Lieberman, J.R., Crystal, R.G., and Hidaka, C. Combined bone morphogenetic protein-2 and -7 gene transfer enhances osteoblastic differentiation and spine fusion in a rodent model. J Bone Miner Res 19, 2021, 2004.

22. Cho, T.J., Gerstenfeld, L.C., and Einhorn, T.A. Differential temporal expression of members of the transforming growth factor beta superfamily during murine fracture healing. J Bone Miner Res 17, 513, 2002.

23. Ripamonti, U., Crooks, J., Petit, J.C., and Rueger, D.C. Periodontal tissue regeneration by combined applications of recombinant human osteogenic protein-1 and bone morphogenetic protein-2. A pilot study in Chacma baboons (Papio ursinus). Eur J Oral Sci 109, 241, 2001.

24. Israel, D.I., Nove, J., Kerns, K.M., Kaufman, R.J., Rosen, V., Cox, K.A., and Wozney, J.M. Heterodimeric bone morphogenetic proteins show enhanced activity in vitro and in vivo. Growth Factors 13, 291, 1996.

25. Aono, A., Hazama, M., Notoya, K., Taketomi, S., Yamasaki, H., Tsukuda, R., Sasaki, S., and Fujisawa, Y. Potent ectopic bone-inducing activity of bone morphogenetic protein- $4 / 7$ heterodimer. Biochem Biophys Res Commun 210, 670, 1995.

26. Koh, J.T., Zhao, Z., Wang, Z., Lewis, I.S., Krebsbach, P.H., and Franceschi, R.T. Combinatorial gene therapy with BMP2/ 7 enhances cranial bone regeneration. J Dent Res 87, $845,2008$.

27. Zhao, M., Zhao, Z., Koh, J.T., Jin, T., and Franceschi, R.T. Combinatorial gene therapy for bone regeneration: cooperative interactions between adenovirus vectors expressing bone morphogenetic proteins 2, 4, and 7. J Cell Biochem 95, 1, 2005.

28. Kawai, M., Bessho, K., Maruyama, H., Miyazaki, J., and Yamamoto, T. Simultaneous gene transfer of bone morphogenetic protein (BMP) -2 and BMP-7 by in vivo electroporation induces rapid bone formation and BMP-4 expression. BMC Musculoskelet Disord 7, 62, 2006.

29. Miyazono, K., Maeda, S., and Imamura, T. BMP receptor signaling: transcriptional targets, regulation of signals, and signaling cross-talk. Cytokine Growth Factor Rev 16, 251, 2005.

30. Yanagita, M. BMP antagonists: Their roles in development and involvement in pathophysiology. Cytokine Growth Factor Rev 16, 309, 2005.

31. Wrana, J.L., and Attisano, L. The Smad pathway. Cytokine Growth Factor Rev 11, 5, 2000.

32. Rosen, V., Thies, R.S., and Lyons, K. Signaling pathways in skeletal formation: a role for BMP receptors. Ann N Y Acad Sci 785, 59, 1996.

33. ten Dijke, P., Yamashita, H., Sampath, T.K., Reddi, A.H., Estevez, M., Riddle, D.L., Ichijo, H., Heldin, C.H., and Miyazono, K. Identification of type I receptors for osteogenic protein-1 and bone morphogenetic protein-4. J Biol Chem 269, 16985, 1994.

34. Ebisawa, T., Tada, K., Kitajima, I., Tojo, K., Sampath, T.K., Kawabata, M., Miyazono, K., and Imamura, T. Characterization of bone morphogenetic protein-6 signaling pathways in osteoblast differentiation. J Cell Sci 112 (Pt 20), 3519, 1999.

35. Macias-Silva, M., Hoodless, P.A., Tang, S.J., Buchwald, M., and Wrana, J.L. Specific activation of Smad1 signaling pathways by the BMP7 type I receptor, ALK2. J Biol Chem 273, 25628, 1998.
36. Tsumaki, N., and Yoshikawa, H. The role of bone morphogenetic proteins in endochondral bone formation. $\mathrm{Cy}-$ tokine Growth Factor Rev 16, 279, 2005.

37. Zhu, W., Kim, J., Cheng, C., Rawlins, B.A., Boachie-Adjei, O., Crystal, R.G., and Hidaka, C. Noggin regulation of bone morphogenetic protein (BMP) 2/7 heterodimer activity in vitro. Bone 39, 61, 2006.

38. Lawrence, D.A. Latent-TGF-beta: an overview. Mol Cell Biochem 219, 163, 2001.

39. Annes, J.P., Munger, J.S., and Rifkin, D.B. Making sense of latent TGFbeta activation. J Cell Sci 116, 217, 2003.

40. Janssens, K., ten Dijke, P., Janssens, S., and Van Hul, W. Transforming growth factor-beta1 to the bone. Endocr Rev 26, 743, 2005.

41. Bostrom, M.P., and Asnis, P. Transforming growth factor beta in fracture repair. Clin Orthop Relat Res 355 Suppl, S124, 1998.

42. Duneas, N., Crooks, J., and Ripamonti, U. Transforming growth factor-beta 1: induction of bone morphogenetic protein genes expression during endochondral bone formation in the baboon, and synergistic interaction with osteogenic protein-1 (BMP-7). Growth Factors 15, 259, 1998.

43. Ripamonti, U., Duneas, N., Van Den Heever, B., Bosch, C., and Crooks, J. Recombinant transforming growth factorbeta1 induces endochondral bone in the baboon and synergizes with recombinant osteogenic protein-1 (bone morphogenetic protein-7) to initiate rapid bone formation. J Bone Miner Res 12, 1584, 1997.

44. Bentz, H., Nathan, R.M., Rosen, D.M., Armstrong, R.M., Thompson, A.Y., Segarini, P.R., Mathews, M.C., Dasch, J.R., Piez, K.A., and Seyedin, S.M. Purification and characterization of a unique osteoinductive factor from bovine bone. J Biol Chem 264, 20805, 1989.

45. Bentz, H., Thompson, A.Y., Armstrong, R., Chang, R.J., Piez, K.A., and Rosen, D.M. Transforming growth factorbeta 2 enhances the osteoinductive activity of a bovine bone-derived fraction containing bone morphogenetic protein-2 and 3. Matrix 11, 269, 1991.

46. Heckman, J.D., Ehler, W., Brooks, B.P., Aufdemorte, T.B., Lohmann, C.H., Morgan, T., and Boyan, B.D. Bone morphogenetic protein but not transforming growth factor-beta enhances bone formation in canine diaphyseal nonunions implanted with a biodegradable composite polymer. J Bone Joint Surg Am 81, 1717, 1999.

47. Oest, M.E., Dupont, K.M., Kong, H.-J., Mooney, D.J., and Guldberg, R.E. Delivery of BMP-2 \& TGF-beta3 additively enhance functional repair of segmental defects. Proceedings of the 53rd Meeting of the Orthopedic Research Society, San Diego, CA, February 10-14, 2007.

48. Si, X., Jin, Y., and Yang, L. Induction of new bone by ceramic bovine bone with recombinant human bone morphogenetic protein 2 and transforming growth factor beta. Int J Oral Maxillofac Surg 27, 310, 1998.

49. Simmons, C.A., Alsberg, E., Hsiong, S., Kim, W.J., and Mooney, D.J. Dual growth factor delivery and controlled scaffold degradation enhance in vivo bone formation by transplanted bone marrow stromal cells. Bone 35, 562, 2004.

50. Sumner, D.R., Turner, T.M., Urban, R.M., Virdi, A.S., and Inoue, N. Additive enhancement of implant fixation following combined treatment with rhTGF-beta2 and rhBMP2 in a canine model. J Bone Joint Surg Am 88, 806, 2006.

51. Otsuru, S., Tamai, K., Yamazaki, T., Yoshikawa, H., and Kaneda, Y. Bone marrow-derived osteoblast progenitor cells 
in circulating blood contribute to ectopic bone formation in mice. Biochem Biophys Res Commun 354, 453, 2007.

52. Ramoshebi, L.N., and Ripamonti, U. Osteogenic protein-1, a bone morphogenetic protein, induces angiogenesis in the chick chorioallantoic membrane and synergizes with basic fibroblast growth factor and transforming growth factorbeta1. Anat Rec 259, 97, 2000.

53. Fromigue, O., Marie, P.J., and Lomri, A. Bone morphogenetic protein-2 and transforming growth factor-beta2 interact to modulate human bone marrow stromal cell proliferation and differentiation. J Cell Biochem 68, 411, 1998.

54. Eswarakumar, V.P., Lax, I., and Schlessinger, J. Cellular signaling by fibroblast growth factor receptors. Cytokine Growth Factor Rev 16, 139, 2005.

55. Schmid, G.J., Kobayashi, C., Sandell, L.J., and Ornitz, D.M. Fibroblast growth factor expression during skeletal fracture healing in mice. Dev Dyn 238, 766, 2009.

56. Bourque, W.T., Gross, M., and Hall, B.K. Expression of four growth factors during fracture repair. Int J Dev Biol 37, 573, 1993.

57. Marie, P.J. Fibroblast growth factor signaling controlling osteoblast differentiation. Gene 316, 23, 2003.

58. Kato, T., Kawaguchi, H., Hanada, K., Aoyama, I., Hiyama, Y., Nakamura, T., Kuzutani, K., Tamura, M., Kurokawa, T., and Nakamura, K. Single local injection of recombinant fibroblast growth factor-2 stimulates healing of segmental bone defects in rabbits. J Orthop Res 16, 654, 1998.

59. Kawaguchi, H., Kurokawa, T., Hanada, K., Hiyama, Y., Tamura, M., Ogata, E., and Matsumoto, T. Stimulation of fracture repair by recombinant human basic fibroblast growth factor in normal and streptozotocin-diabetic rats. Endocrinology 135, 774, 1994.

60. Nakamura, T., Hara, Y., Tagawa, M., Tamura, M., Yuge, T., Fukuda, H., and Nigi, H. Recombinant human basic fibroblast growth factor accelerates fracture healing by enhancing callus remodeling in experimental dog tibial fracture. J Bone Miner Res 13, 942, 1998.

61. Okazaki, H., Kurokawa, T., Nakamura, K., Matsushita, T., Mamada, K., and Kawaguchi, H. Stimulation of bone formation by recombinant fibroblast growth factor- 2 in callotasis bone lengthening of rabbits. Calcif Tissue Int 64, 542, 1999.

62. Radomsky, M.L., Aufdemorte, T.B., Swain, L.D., Fox, W.C., Spiro, R.C., and Poser, J.W. Novel formulation of fibroblast growth factor-2 in a hyaluronan gel accelerates fracture healing in nonhuman primates. J Orthop Res 17, 607, 1999.

63. Radomsky, M.L., Thompson, A.Y., Spiro, R.C., and Poser, J.W. Potential role of fibroblast growth factor in enhancement of fracture healing. Clin Orthop Relat Res 355 Suppl, S283, 1998.

64. Nakajima, F., Ogasawara, A., Goto, K., Moriya, H., Ninomiya, Y., Einhorn, T.A., and Yamazaki, M. Spatial and temporal gene expression in chondrogenesis during fracture healing and the effects of basic fibroblast growth factor. J Orthop Res 19, 935, 2001.

65. Kubota, K., Iseki, S., Kuroda, S., Oida, S., Iimura, T., Duarte, W.R., Ohya, K., Ishikawa, I., and Kasugai, S. Synergistic effect of fibroblast growth factor- 4 in ectopic bone formation induced by bone morphogenetic protein-2. Bone 31, 465, 2002.

66. Fujimura, K., Bessho, K., Okubo, Y., Kusumoto, K., Segami, N., and lizuka, T. The effect of fibroblast growth factor- 2 on the osteoinductive activity of recombinant human bone morphogenetic protein-2 in rat muscle. Arch Oral Biol 47, 577, 2002.

67. Kakudo, N., Kusumoto, K., Kuro, A., and Ogawa, Y. Effect of recombinant human fibroblast growth factor-2 on intramuscular ectopic osteoinduction by recombinant human bone morphogenetic protein-2 in rats. Wound Repair Regen 14, 336, 2006.

68. Nakamura, Y., Tensho, K., Nakaya, H., Nawata, M., Okabe, T., and Wakitani, S. Low dose fibroblast growth factor-2 (FGF-2) enhances bone morphogenetic protein-2 (BMP-2)induced ectopic bone formation in mice. Bone 36, 399, 2005.

69. Tanaka, E., Ishino, Y., Sasaki, A., Hasegawa, T., Watanabe, M., Dalla-Bona, D.A., Yamano, E., van Eijden, T.M., and Tanne, K. Fibroblast growth factor-2 augments recombinant human bone morphogenetic protein-2-induced osteoinductive activity. Ann Biomed Eng 34, 717, 2006.

70. Hanada, K., Dennis, J.E., and Caplan, A.I. Stimulatory effects of basic fibroblast growth factor and bone morphogenetic protein-2 on osteogenic differentiation of rat bone marrow-derived mesenchymal stem cells. J Bone Miner Res 12, 1606, 1997.

71. Fakhry, A., Ratisoontorn, C., Vedhachalam, C., Salhab, I., Koyama, E., Leboy, P., Pacifici, M., Kirschner, R.E., and Nah, H.D. Effects of FGF-2/-9 in calvarial bone cell cultures: differentiation stage-dependent mitogenic effect, inverse regulation of BMP-2 and noggin, and enhancement of osteogenic potential. Bone 36, 254, 2005.

72. Martin, I., Muraglia, A., Campanile, G., Cancedda, R., and Quarto, R. Fibroblast growth factor-2 supports ex vivo expansion and maintenance of osteogenic precursors from human bone marrow. Endocrinology 138, 4456, 1997.

73. Quarto, N., and Longaker, M.T. FGF-2 inhibits osteogenesis in mouse adipose tissue-derived stromal cells and sustains their proliferative and osteogenic potential state. Tissue Eng 12, 1405, 2006.

74. Varkey, M., Kucharski, C., Haque, T., Sebald, W., and Uludag, H. In vitro osteogenic response of rat bone marrow cells to bFGF and BMP-2 treatments. Clin Orthop Relat Res 443, 113, 2006.

75. Singhatanadgit, W., Salih, V., and Olsen, I. Up-regulation of bone morphogenetic protein receptor IB by growth factors enhances BMP-2-induced human bone cell functions. J Cell Physiol 209, 912, 2006.

76. Conover, C.A. Insulin-like growth factor-binding proteins and bone metabolism. Am J Physiol Endocrinol Metab 294, E10, 2008.

77. Niu, T., and Rosen, C.J. The insulin-like growth factor-I gene and osteoporosis: a critical appraisal. Gene 361, 38, 2005.

78. Rosen, C.J. Insulin-like growth factor I and bone mineral density: experience from animal models and human observational studies. Best Pract Res Clin Endocrinol Metab 18, 423, 2004.

79. Geusens, P.P., and Boonen, S. Osteoporosis and the growth hormone-insulin-like growth factor axis. Horm Res 58 Suppl 3, 49, 2002.

80. Fowlkes, J.L., Thrailkill, K.M., Liu, L., Wahl, E.C., Bunn, R.C., Cockrell, G.E., Perrien, D.S., Aronson, J., and Lumpkin, C.K., Jr. Effects of systemic and local administration of recombinant human IGF-I (rhIGF-I) on de novo bone formation in an aged mouse model. J Bone Miner Res 21, 1359, 2006.

81. Meinel, L., Zoidis, E., Zapf, J., Hassa, P., Hottiger, M.O., Auer, J.A., Schneider, R., Gander, B., Luginbuehl, V., 
Bettschart-Wolfisberger, R., Illi, O.E., Merkle, H.P., and von Rechenberg, B. Localized insulin-like growth factor I delivery to enhance new bone formation. Bone 33, 660, 2003.

82. Raiche, A.T., and Puleo, D.A. In vitro effects of combined and sequential delivery of two bone growth factors. Biomaterials 25, 677, 2004.

83. Yeh, L.C., Adamo, M.L., Olson, M.S., and Lee, J.C. Osteogenic protein-1 and insulin-like growth factor I synergistically stimulate rat osteoblastic cell differentiation and proliferation. Endocrinology 138, 4181, 1997.

84. Lan, J., Wang, Z., Wang, Y., Wang, J., and Cheng, X. The effect of combination of recombinant human bone morphogenetic protein-2 and basic fibroblast growth factor or insulin-like growth factor-I on dental implant osseointegration by confocal laser scanning microscopy. J Periodontol 77, 357, 2006.

85. Blumenfeld, I., Srouji, S., Lanir, Y., Laufer, D., and Livne, E. Enhancement of bone defect healing in old rats by TGFbeta and IGF-1. Exp Gerontol 37, 553, 2002.

86. Srouji, S., Blumenfeld, I., Rachmiel, A., and Livne, E. Bone defect repair in rat tibia by TGF-beta1 and IGF-1 released from hydrogel scaffold. Cell Tissue Bank 5, 223, 2004.

87. Srouji, S., Rachmiel, A., Blumenfeld, I., and Livne, E. Mandibular defect repair by TGF-beta and IGF-1 released from a biodegradable osteoconductive hydrogel. J Craniomaxillofac Surg 33, 79, 2005.

88. Schmidmaier, G., Wildemann, B., Gabelein, T., Heeger, J., Kandziora, F., Haas, N.P., and Raschke, M. Synergistic effect of IGF-I and TGF-beta1 on fracture healing in rats: single versus combined application of IGF-I and TGF-beta1. Acta Orthop Scand 74, 604, 2003.

89. Kveiborg, M., Flyvbjerg, A., Eriksen, E.F., and Kassem, M. Transforming growth factor-beta1 stimulates the production of insulin-like growth factor-I and insulin-like growth factor-binding protein-3 in human bone marrow stromal osteoblast progenitors. J Endocrinol 169, 549, 2001.

90. Okazaki, R., Durham, S.K., Riggs, B.L., and Conover, C.A. Transforming growth factor-beta and forskolin increase all classes of insulin-like growth factor-I transcripts in normal human osteoblast-like cells. Biochem Biophys Res Commun 207, 963, 1995.

91. Giannobile, W.V., Whitson, S.W., and Lynch, S.E. Non-coordinate control of bone formation displayed by growth factor combinations with IGF-I. J Dent Res 76, 1569, 1997.

92. Kasperk, C.H., Wergedal, J.E., Mohan, S., Long, D.L., Lau, K.H., and Baylink, D.J. Interactions of growth factors present in bone matrix with bone cells: effects on DNA synthesis and alkaline phosphatase. Growth Factors 3, 147, 1990.

93. Mott, D.A., Mailhot, J., Cuenin, M.F., Sharawy, M., and Borke, J. Enhancement of osteoblast proliferation in vitro by selective enrichment of demineralized freeze-dried bone allograft with specific growth factors. J Oral Implantol 28, 57, 2002.

94. Pfeilschifter, J., Oechsner, M., Naumann, A., Gronwald, R.G., Minne, H.W., and Ziegler, R. Stimulation of bone matrix apposition in vitro by local growth factors: a comparison between insulin-like growth factor I, plateletderived growth factor, and transforming growth factor beta. Endocrinology 127, 69, 1990.

95. Gerstenfeld, L.C., Cullinane, D.M., Barnes, G.L., Graves, D.T., and Einhorn, T.A. Fracture healing as a post-natal developmental process: molecular, spatial, and temporal aspects of its regulation. J Cell Biochem 88, 873, 2003.
96. Hansen-Algenstaedt, N., Joscheck, C., Wolfram, L., Schaefer, C., Muller, I., Bottcher, A., Deuretzbacher, G., Wiesner, L., Leunig, M., Algenstaedt, P., and Ruther, W. Sequential changes in vessel formation and micro-vascular function during bone repair. Acta Orthop 77, 429, 2006.

97. Neufeld, G., Cohen, T., Gengrinovitch, S., and Poltorak, Z. Vascular endothelial growth factor (VEGF) and its receptors. FASEB J 13, 9, 1999.

98. Street, J., Bao, M., deGuzman, L., Bunting, S., Peale, F.V., Jr., Ferrara, N., Steinmetz, H., Hoeffel, J., Cleland, J.L., Daugherty, A., van Bruggen, N., Redmond, H.P., Carano, R.A., and Filvaroff, E.H. Vascular endothelial growth factor stimulates bone repair by promoting angiogenesis and bone turnover. Proc Natl Acad Sci U S A 99, 9656, 2002.

99. Eckardt, H., Ding, M., Lind, M., Hansen, E.S., Christensen, K.S., and Hvid, I. Recombinant human vascular endothelial growth factor enhances bone healing in an experimental nonunion model. J Bone Joint Surg Br 87, 1434, 2005.

100. Kaigler, D., Wang, Z., Horger, K., Mooney, D.J., and Krebsbach, P.H. VEGF scaffolds enhance angiogenesis and bone regeneration in irradiated osseous defects. J Bone Miner Res 21, 735, 2006.

101. Peng, H., Usas, A., Olshanski, A., Ho, A.M., Gearhart, B., Cooper, G.M., and Huard, J. VEGF improves, whereas sFlt1 inhibits, BMP2-induced bone formation and bone healing through modulation of angiogenesis. J Bone Miner Res 20, 2017, 2005.

102. Kaigler, D., Krebsbach, P.H., West, E.R., Horger, K., Huang, Y.C., and Mooney, D.J. Endothelial cell modulation of bone marrow stromal cell osteogenic potential. FASEB J 19, 665, 2005.

103. Wang, D.S., Miura, M., Demura, H., and Sato, K. Anabolic effects of 1,25-dihydroxyvitamin D3 on osteoblasts are enhanced by vascular endothelial growth factor produced by osteoblasts and by growth factors produced by endothelial cells. Endocrinology 138, 2953, 1997.

104. Deckers, M.M., van Bezooijen, R.L., van der Horst, G., Hoogendam, J., van Der Bent, C., Papapoulos, S.E., and Lowik, C.W. Bone morphogenetic proteins stimulate angiogenesis through osteoblast-derived vascular endothelial growth factor A. Endocrinology 143, 1545, 2002.

105. Kozawa, O., Matsuno, H., and Uematsu, T. Involvement of p70 S6 kinase in bone morphogenetic protein signaling: vascular endothelial growth factor synthesis by bone morphogenetic protein-4 in osteoblasts. J Cell Biochem 81, 430, 2001.

106. Yeh, L.C., and Lee, J.C. Osteogenic protein-1 increases gene expression of vascular endothelial growth factor in primary cultures of fetal rat calvaria cells. Mol Cell Endocrinol 153, 113, 1999.

107. Peng, H., Wright, V., Usas, A., Gearhart, B., Shen, H.C., Cummins, J., and Huard, J. Synergistic enhancement of bone formation and healing by stem cell-expressed VEGF and bone morphogenetic protein-4. J Clin Invest 110, 751, 2002.

108. Samee, M., Kasugai, S., Kondo, H., Ohya, K., Shimokawa, H., and Kuroda, S. Bone morphogenetic protein-2 (BMP-2) and vascular endothelial growth factor (VEGF) transfection to human periosteal cells enhances osteoblast differentiation and bone formation. J Pharmacol Sci 108, 18, 2008.

109. Huang, Y.C., Kaigler, D., Rice, K.G., Krebsbach, P.H., and Mooney, D.J. Combined angiogenic and osteogenic factor delivery enhances bone marrow stromal cell-driven bone regeneration. J Bone Miner Res 20, 848, 2005. 
110. Kempen, D.H., Lu, L., Heijink, A., Hefferan, T.E., Creemers, L.B., Maran, A., Yaszemski, M.J., and Dhert, W.J. Effect of local sequential VEGF and BMP-2 delivery on ectopic and orthotopic bone regeneration. Biomaterials 30, 2816, 2009.

111. Patel, Z.S., Young, S., Tabata, Y., Jansen, J.A., Wong, M.E., and Mikos, A.G. Dual delivery of an angiogenic and an osteogenic growth factor for bone regeneration in a critical size defect model. Bone 43, 931, 2008.

112. Fiedler, J., Leucht, F., Waltenberger, J., Dehio, C., and Brenner, R.E. VEGF-A and PlGF-1 stimulate chemotactic migration of human mesenchymal progenitor cells. Biochem Biophys Res Commun 334, 561, 2005.

113. Fiedler, J., Roderer, G., Gunther, K.P., and Brenner, R.E. BMP-2, BMP-4, and PDGF-bb stimulate chemotactic migration of primary human mesenchymal progenitor cells. J Cell Biochem 87, 305, 2002.

114. Hollinger, J.O., Hart, C.E., Hirsch, S.N., Lynch, S., and Friedlaender, G.E. Recombinant human platelet-derived growth factor: biology and clinical applications. J Bone Joint Surg Am 90 Suppl 1, 48, 2008.

115. Greenberg, J.I., Shields, D.J., Barillas, S.G., Acevedo, L.M., Murphy, E., Huang, J., Scheppke, L., Stockmann, C., Johnson, R.S., Angle, N., and Cheresh, D.A. A role for VEGF as a negative regulator of pericyte function and vessel maturation. Nature 456, 809, 2008.

116. Zhang, F., Tang, Z., Hou, X., Lennartsson, J., Li, Y., Koch, A.W., Scotney, P., Lee, C., Arjunan, P., Dong, L., Kumar, A., Rissanen, T.T., Wang, B., Nagai, N., Fons, P., Fariss, R., Zhang, Y., Wawrousek, E., Tansey, G., Raber, J., Fong, G.H., Ding, H., Greenberg, D.A., Becker, K.G., Herbert, J.M., Nash, A., Yla-Herttuala, S., Cao, Y., Watts, R.J., and Li, $X$. VEGF-B is dispensable for blood vessel growth but critical for their survival, and VEGF-B targeting inhibits pathological angiogenesis. Proc Natl Acad Sci U S A 106, 6152, 2009.

117. Marden, L.J., Fan, R.S., Pierce, G.F., Reddi, A.H., and Hollinger, J.O. Platelet-derived growth factor inhibits bone regeneration induced by osteogenin, a bone morphogenetic protein, in rat craniotomy defects. J Clin Invest 92, 2897, 1993.

118. Ranly, D.M., McMillan, J., Keller, T., Lohmann, C.H., Meunch, T., Cochran, D.L., Schwartz, Z., and Boyan, B.D. Platelet-derived growth factor inhibits demineralized bone matrix-induced intramuscular cartilage and bone formation. A study of immunocompromised mice. J Bone Joint Surg Am 87, 2052, 2005.

119. Kubota, K., Sakikawa, C., Katsumata, M., Nakamura, T., and Wakabayashi, K. Platelet-derived growth factor BB secreted from osteoclasts acts as an osteoblastogenesis inhibitory factor. J Bone Miner Res 17, 257, 2002.

120. Hock, J.M., and Canalis, E. Platelet-derived growth factor enhances bone cell replication, but not differentiated function of osteoblasts. Endocrinology 134, 1423, 1994.

121. Canalis, E., McCarthy, T.L., and Centrella, M. Effects of platelet-derived growth factor on bone formation in vitro. J Cell Physiol 140, 530, 1989.

122. Cochran, D.L., Rouse, C.A., Lynch, S.E., and Graves, D.T. Effects of platelet-derived growth factor isoforms on calcium release from neonatal mouse calvariae. Bone 14, 53, 1993.

123. Lynch, S.E., Trippel, S.B., Finkelman, R.D., Hernandez, R.A., Kiritsy, C.P., and Antoniades, H.N. The combination of platelet-derived growth factor-BB and insulin-like growth factor-I stimulates bone repair in adult Yucatan miniature pigs. Wound Repair Regen 2, 182, 1994.

124. Giannobile, W.V., Finkelman, R.D., and Lynch, S.E. Comparison of canine and non-human primate animal models for periodontal regenerative therapy: results following a single administration of PDGF/IGF-I. J Periodontol 65, 1158, 1994.

125. Lynch, S.E., Buser, D., Hernandez, R.A., Weber, H.P., Stich, H., Fox, C.H., and Williams, R.C. Effects of the plateletderived growth factor/insulin-like growth factor-I combination on bone regeneration around titanium dental implants. Results of a pilot study in beagle dogs. J Periodontol 62, 710, 1991.

126. Lynch, S.E., de Castilla, G.R., Williams, R.C., Kiritsy, C.P., Howell, T.H., Reddy, M.S., and Antoniades, H.N. The effects of short-term application of a combination of plateletderived and insulin-like growth factors on periodontal wound healing. J Periodontol 62, 458, 1991.

127. Lynch, S.E., Williams, R.C., Polson, A.M., Howell, T.H., Reddy, M.S., Zappa, U.E., and Antoniades, H.N. A combination of platelet-derived and insulin-like growth factors enhances periodontal regeneration. J Clin Periodontol 16, $545,1989$.

128. Howell, T.H., Fiorellini, J.P., Paquette, D.W., Offenbacher, S., Giannobile, W.V., and Lynch, S.E. A phase I/II clinical trial to evaluate a combination of recombinant human platelet-derived growth factor-BB and recombinant human insulin-like growth factor-I in patients with periodontal disease. J Periodontol 68, 1186, 1997.

129. Giannobile, W.V., Hernandez, R.A., Finkelman, R.D., Ryan, S., Kiritsy, C.P., D'Andrea, M., and Lynch, S.E. Comparative effects of platelet-derived growth factor-BB and insulin-like growth factor-I, individually and in combination, on periodontal regeneration in Macaca fascicularis. J Periodontal Res 31, 301, 1996.

130. Boyapati, L., and Wang, H.L. The role of platelet-rich plasma in sinus augmentation: a critical review. Implant Dent 15, 160, 2006.

131. Kitoh, H., Kitakoji, T., Tsuchiya, H., Mitsuyama, H., Nakamura, H., Katoh, M., and Ishiguro, N. Transplantation of marrow-derived mesenchymal stem cells and platelet-rich plasma during distraction osteogenesis-a preliminary result of three cases. Bone 35, 892, 2004.

132. Savarino, L., Cenni, E., Tarabusi, C., Dallari, D., Stagni, C., Cenacchi, A., Fornasari, P.M., Giunti, A., and Baldini, N. Evaluation of bone healing enhancement by lyophilized bone grafts supplemented with platelet gel: a standardized methodology in patients with tibial osteotomy for genu varus. J Biomed Mater Res B Appl Biomater 76, 364, 2006.

133. Simman, R., Hoffmann, A., Bohinc, R.J., Peterson, W.C., and Russ, A.J. Role of platelet-rich plasma in acceleration of bone fracture healing. Ann Plast Surg 61, 337, 2008.

134. Park, E.J., Kim, E.S., Weber, H.P., Wright, R.F., and Mooney, D.J. Improved bone healing by angiogenic factorenriched platelet-rich plasma and its synergistic enhancement by bone morphogenetic protein-2. Int $\mathrm{J}$ Oral Maxillofac Implants 23, 818, 2008.

135. Jung, R.E., Schmoekel, H.G., Zwahlen, R., Kokovic, V., Hammerle, C.H., and Weber, F.E. Platelet-rich plasma and fibrin as delivery systems for recombinant human bone morphogenetic protein-2. Clin Oral Implants Res 16, 676, 2005. 
136. Calori, G.M., D'Avino, M., Tagliabue, L., Albisetti, W., d'Imporzano, M., and Peretti, G. An ongoing research for evaluation of treatment with BMPs or AGFs in long bone non-union: protocol description and preliminary results. Injury 37 Suppl 3, S43, 2006.

137. van den Dolder, J., Mooren, R., Vloon, A.P., Stoelinga, P.J., and Jansen, J.A. Platelet-rich plasma: quantification of growth factor levels and the effect on growth and differentiation of rat bone marrow cells. Tissue Eng 12, 3067, 2006.

138. Lorenzo, J., Horowitz, M., and Choi, Y. Osteoimmunology: interactions of the bone and immune system. Endocr Rev 29, 403, 2008.

139. Nakashima, T., and Takayanagi, H. The dynamic interplay between osteoclasts and the immune system. Arch Biochem Biophys 473, 166, 2008.

140. Takayanagi, H. Osteoimmunology: shared mechanisms and crosstalk between the immune and bone systems. Nat Rev Immunol 7, 292, 2007.

141. Weitzmann, M.N., and Pacifici, R. The role of T lymphocytes in bone metabolism. Immunol Rev 208, 154, 2005.

142. Du, X., and Williams, D.A. Interleukin-11: review of molecular, cell biology, and clinical use. Blood 89, 3897, 1997.

143. Du, X.X., and Williams, D.A. Interleukin-11: a multifunctional growth factor derived from the hematopoietic microenvironment. Blood 83, 2023, 1994.

144. Girasole, G., Passeri, G., Jilka, R.L., and Manolagas, S.C. Interleukin-11: a new cytokine critical for osteoclast development. J Clin Invest 93, 1516, 1994.

145. Hill, P.A., Tumber, A., Papaioannou, S., and Meikle, M.C. The cellular actions of interleukin-11 on bone resorption in vitro. Endocrinology 139, 1564, 1998.

146. Suga, K., Saitoh, M., Fukushima, S., Takahashi, K., Nara, H., Yasuda, S., and Miyata, K. Interleukin-11 induces osteoblast differentiation and acts synergistically with bone morphogenetic protein-2 in C3H10T1/2 cells. J Interferon Cytokine Res 21, 695, 2001.

147. Suga, K., Saitoh, M., Kokubo, S., Fukushima, S., Kaku, S., Yasuda, S., and Miyata, K. Interleukin-11 acts synergistically with bone morphogenetic protein-2 to accelerate bone formation in a rat ectopic model. J Interferon Cytokine Res 23, 203, 2003.

148. Suga, K., Saitoh, M., Kokubo, S., Nozaki, K., Fukushima, S., Yasuda, S., Sasamata, M., and Miyata, K. Synergism between interleukin-11 and bone morphogenetic protein-2 in the healing of segmental bone defects in a rabbit model. J Interferon Cytokine Res 24, 343, 2004.

149. Lotinun, S., Sibonga, J.D., and Turner, R.T. Differential effects of intermittent and continuous administration of parathyroid hormone on bone histomorphometry and gene expression. Endocrine 17, 29, 2002.

150. Qin, L., Raggatt, L.J., and Partridge, N.C. Parathyroid hormone: a double-edged sword for bone metabolism. Trends Endocrinol Metab 15, 60, 2004.

151. Neer, R.M., Arnaud, C.D., Zanchetta, J.R., Prince, R., Gaich, G.A., Reginster, J.Y., Hodsman, A.B., Eriksen, E.F., IshShalom, S., Genant, H.K., Wang, O., and Mitlak, B.H. Effect of parathyroid hormone (1-34) on fractures and bone mineral density in postmenopausal women with osteoporosis. N Engl J Med 344, 1434, 2001.

152. Dobnig, H., and Turner, R.T. Evidence that intermittent treatment with parathyroid hormone increases bone formation in adult rats by activation of bone lining cells. Endocrinology 136, 3632, 1995.
153. Jilka, R.L., Weinstein, R.S., Bellido, T., Roberson, P., Parfitt, A.M., and Manolagas, S.C. Increased bone formation by prevention of osteoblast apoptosis with parathyroid hormone. J Clin Invest 104, 439, 1999.

154. Leaffer, D., Sweeney, M., Kellerman, L.A., Avnur, Z., Krstenansky, J.L., Vickery, B.H., and Caulfield, J.P. Modulation of osteogenic cell ultrastructure by RS-23581, an analog of human parathyroid hormone (PTH)-related peptide-(1-34), and bovine PTH-(1-34). Endocrinology 136, 3624, 1995.

155. Onyia, J.E., Bidwell, J., Herring, J., Hulman, J., and Hock, J.M. In vivo, human parathyroid hormone fragment (hPTH 1-34) transiently stimulates immediate early response gene expression, but not proliferation, in trabecular bone cells of young rats. Bone 17, 479, 1995.

156. Kabasawa, Y., Asahina, I., Gunji, A., and Omura, K. Administration of parathyroid hormone, prostaglandin E2, or 1-alpha,25-dihydroxyvitamin D3 restores the bone inductive activity of rhBMP-2 in aged rats. DNA Cell Biol 22, 541, 2003.

157. Horiuchi, H., Saito, N., Kinoshita, T., Wakabayashi, S., Tsutsumimoto, T., Otsuru, S., and Takaoka, K. Enhancement of recombinant human bone morphogenetic protein-2 (rhBMP2)-induced new bone formation by concurrent treatment with parathyroid hormone and a phosphodiesterase inhibitor, pentoxifylline. J Bone Miner Metab 22, 329, 2004.

158. Kempen, D.H.R., Lu, L., Hefferan, T.E., Creemers, L.B., Heijink, A., Maran, A., Dhert, W.J.A., and Yaszemski, M.J. Enhanced BMP-2 induced ectopic and orthotopic bone formation by intermittent $\mathrm{PTH}(1-34)$ administration. Tissue Eng A 2010 Jul 28 [Epub ahead of print].

159. Morgan, E.F., Mason, Z.D., Bishop, G., Davis, A.D., Wigner, N.A., Gerstenfeld, L.C., and Einhorn, T.A. Combined effects of recombinant human BMP-7 (rhBMP-7) and parathyroid hormone (1-34) in metaphyseal bone healing. Bone 43, 1031, 2008.

160. Cui, L., Ma, Y.F., Yao, W., Zhou, H., Setterberg, R.B., Liang, T.C., and Jee, W.S. Cancellous bone of aged rats maintains its capacity to respond vigorously to the anabolic effects of prostaglandin E2 by modeling-dependent bone gain. J Bone Miner Metab 19, 29, 2001.

161. Zhou, H., Ma, Y.F., Yao, W., Cui, L., Setterberg, R., Liang, C.T., and Jee, W.S. Lumbar vertebral cancellous bone is capable of responding to PGE2 treatment by stimulating both modeling and remodeling-dependent bone gain in aged male rats. Calcif Tissue Int 68, 179, 2001.

162. Montero-Odasso, M., and Duque, G. Vitamin D in the aging musculoskeletal system: an authentic strength preserving hormone. Mol Aspects Med 26, 203, 2005.

163. Dawson-Hughes, B., Harris, S.S., Krall, E.A., and Dallal, G.E. Effect of calcium and vitamin D supplementation on bone density in men and women 65 years of age or older. $\mathrm{N}$ Engl J Med 337, 670, 1997.

164. Ooms, M.E., Roos, J.C., Bezemer, P.D., van der Vijgh, W.J., Bouter, L.M., and Lips, P. Prevention of bone loss by vitamin D supplementation in elderly women: a randomized double-blind trial. J Clin Endocrinol Metab 80, 1052, 1995.

165. Shevde, N.K., Plum, L.A., Clagett-Dame, M., Yamamoto, H., Pike, J.W., and DeLuca, H.F. A potent analog of 1alpha,25-dihydroxyvitamin D3 selectively induces bone formation. Proc Natl Acad Sci U S A 99, 13487, 2002.

166. Ono, I., Tateshita, T., Takita, H., and Kuboki, Y. Promotion of the osteogenetic activity of recombinant human bone 
morphogenetic protein by basic fibroblast growth factor. J Craniofac Surg 7, 418, 1996.

167. Takita, H., Tsuruga, E., Ono, I., and Kuboki, Y. Enhancement by bFGF of osteogenesis induced by rhBMP-2 in rats. Eur J Oral Sci 105, 588, 1997.

168. Vonau, R.L., Bostrom, M.P., Aspenberg, P., and Sams, A.E. Combination of growth factors inhibits bone ingrowth in the bone harvest chamber. Clin Orthop Relat Res 386, 243, 2001.

169. Minamide, A., Yoshida, M., Kawakami, M., Okada, M., Enyo, Y., Hashizume, H., and Boden, S.D. The effects of bone morphogenetic protein and basic fibroblast growth factor on cultured mesenchymal stem cells for spine fusion. Spine 32, 1067, 2007.
Address correspondence to: Laura B. Creemers, Ph.D. Department of Orthopedics, G05.228 University Medical Center

P.O. Box 85500 3508 GA Utrecht The Netherlands

E-mail: 1.b.creemers@umcutrecht.nl

Received: March 22, 2010

Accepted: August 19, 2010

Online Publication Date: October 26, 2010 